\title{
HOLOCENE STRATIGRAPHY IN THE PARANAGUÁ BAY ESTUARY, SOUTHERN BRAZIL
}

\author{
GUILHERME C. LESSA ${ }^{*}$, STEPHEN R. MEYERS ${ }^{2}$, AND EDUARDO MARONE${ }^{1}$ \\ ${ }^{1}$ Centro de Estudos do Mar-UFPR, C.P. 43, Paranaguá (PR), 83255-000, Brazil \\ * Present Address: Laboratório de Estudos Costeiros-Centro de Pesquisa em Geofísica e Geologia-UFBA, Instituto de Geociências, \\ Campus Universitário de Ondina, Salvador (BA) 40210-340, Brazil \\ ${ }^{2}$ Antioch College, 795 Livermore St., Yellow Springs, Ohio 45387, U.S.A.
}

\begin{abstract}
The Paranaguá Bay estuary is a $50 \mathrm{~km}$ long microtidal barrier estuary that is still far from infilled even after $3.5 \mathrm{~m}$ of continuous sea-level fall during the last $\mathbf{5 0 0 0}$ years. Data derived from several independent studies, including surface sediment samples, jet-probe cores, vibracores, and seismic records, were compiled in order to provide an assessment of the Quaternary stratigraphy of the estuary. The estuary displays the longitudinal tripartite zonation of surface sedimentary facies (marine sand-estuarine mud-fluvial sand) that is characteristic of many coastal-plain estuaries. Five sedimentary facies were identified overlying the bedrock. Pre-Holocene fluvial and continental deposits within the paleo-valley form the substrate for the more recent sedimentation. A transgressive mud facies marks the initial stages of estuary inundation. This deposit is observed only in the lower half of the estuary, where greater accommodation space existed and less intensive tidal scouring associated with the subsequent deposition of the transgressive sand facies occurred. The onset of the regressive stage is marked by the deposition of the regressive mud facies, which is presently the most extensive sedimentary deposit within the estuary. The regressive sand facies, which is composed of fluvially derived sediments and is restricted to the head of the estuary, is the least developed sedimentary facies. The vertical succession of the sedimentary facies shows an almost complete stratigraphic sequence and the presence of several bounding surfaces: a transgressive surface, a maximum flooding surface, a tidal ravinement surface, and a tidal diastem. A comparison of the Paranaguá Bay, Gironde, and James estuaries, all of similar size, illustrates various stages of sequence development in modern incisedvalley systems.
\end{abstract}

\section{INTRODUCTION}

Facies models have been proposed for many estuaries around the globe, either in the commonly transgressing coasts of the northern hemisphere (Frey and Howard 1986; Nichols et al. 1991; Shi and Lamb 1991; Boyd and Honig 1992; Allen and Posamentier 1993, 1994; Zhang and Li 1996) or in the generally regressive coasts of the southern hemisphere (Roy 1984; Woodroffe et al. 1989; Nichol 1991; Chappell 1993; Davis and Healy 1993; Woodroffe et al. 1993; Roy 1994; Lessa and Masselink 1995). Although variations can occur in every estuary because of distinct sea-level trends and geological inheritance, as well as to differing degrees of river runoff, accommodation space, and tide and wave influence, the investigated stratigraphic sequences fit well with the model proposed by Dalrymple et al. (1992) (Fig. 1). In this model, wave-dominated estuaries can be infilled from both ends of the embayment (Boyd et al. 1992): from the ocean side marine sediments are supplied by flood-tidal deltas and washover, while at the landward end rivers form a bay-head delta. Given the right conditions of eustasy, subsidence, and sediment supply, a complete stratigraphic sequence (Van Wagoner et al. 1988) is formed, with the more landward sedimentary facies underlying, and subsequently overlying, the seaward facies (Fig. 1).

The Paranaguá Bay estuary, located on the southeastern coast of Paraná, Brazil, is part of an estuarine system that is still far from infilled even after $3.5 \mathrm{~m}$ of continuous sea-level fall during the last 5000 years. The complete estuarine system incorporates two main water bodies: Paranaguá Bay itself, which stretches for $50 \mathrm{~km}$ on an east-west axis and is about $7 \mathrm{~km}$ wide, and Laranjeiras Bay, which runs along a north-south axis and is approximately $30 \mathrm{~km}$ long and up to $13 \mathrm{~km}$ wide (Fig. 2, inset). A large number of investigations have been carried out on the surface geology of the Paranaguá Bay estuary and the surrounding coastal plain, but very few studies have addressed the nature of the underlying sedimentary units or the geometry of the surface deposits. Bigarella et al. (1978) are the only authors that have given some attention to the subsurface geology of the Paranaguá Bay estuary, by publishing the logs of eight jet-probe cores from an area close to Paranaguá harbor (Fig. 2). In recent years, a large amount of information pertaining to the surface sediment distribution, bathymetry, and nature of the substrate within the estuary has been gathered by many institutions, but no attempt has been made to compile this information or interpret the data in an evolutionary sense.

This investigation intends to: (1) compile and analyze all of the geologic information available at present regarding the Paranaguá Bay estuary, from published and unpublished documents; (2) present an analysis of the observed sedimentary facies contained within the incised-valley fill of the estuary; (3) interpret the facies succession in light of the concepts of sequence stratigraphy; and (4) compare the facies architecture of the Paranaguá Bay estuary to other barrier estuaries of similar size.

\section{DATA SOURCES}

Vibracores \#1 and \#2 provide the only set of unpublished information. Vibracoring was performed with $6 \mathrm{~m}$ aluminum barrels in the channel between Cotinga and Rasa Islands (Fig. 3), at intertidal elevations of approximately $-0.5 \mathrm{~m}$ (vibracore \#1) and $+1.0 \mathrm{~m}$ (vibracore \#2) in relation to mean sea level.

Grain-size analysis of 429 surface sediment samples are available for the entire length of the estuary, from Pontal do Sul to the foothills of the Serra do Mar (Fig. 3; Bigarella et al. 1978). The subsurface sediment information was derived from the logs of six jet-probe cores taken near the harbor area (Bigarella et al. 1978) and 121 jet-probe cores executed between Paranaguá and Antonina (PROGEO 1993). Of these 129 cores, three cores from Bigarella et al. (1978) and 34 cores from PROGEO (1993) (Fig. 3) were used to construct longitudinal and normal stratigraphic cross sections. The PROGEO cores reached a maximum depth of $15 \mathrm{~m}$ below mean sea level (msl), regardless of the depth of the channel. The location of these cores followed the course of the navigation channel (400 m wide) along the estuary, with clusters of cores in some restricted areas. The subsurface samples were described on site by PROGEO, without any further laboratory analysis. The Antonina Harbor Authority, however, provided access to 420 stored sediment samples, from which 217 were recovered, accounting for 73 wells. From these recovered samples it was possible to check the precision of the logs and perform grain-size analysis with some selected samples.

More information on the characteristics of the subsurface geology was given by three seismic surveys (Fig. 3). Six maps at 1:2000 scale were prepared by the Brazilian Harbor Authority (PORTOBRÁS 1988) covering the estuary between Paranaguá and Ponta da Cruz (Fig. 3). Companhia Brasileira de Dragagem (1980) prepared seven more maps at 1:2500 scale covering the area between Paranaguá and Antonina. Finally, seven maps were prepared by ENCAL (1972) at 1:5000 scale, covering the area from Paranaguá to both of the estuary entrances. The bathymetry of the estuary 


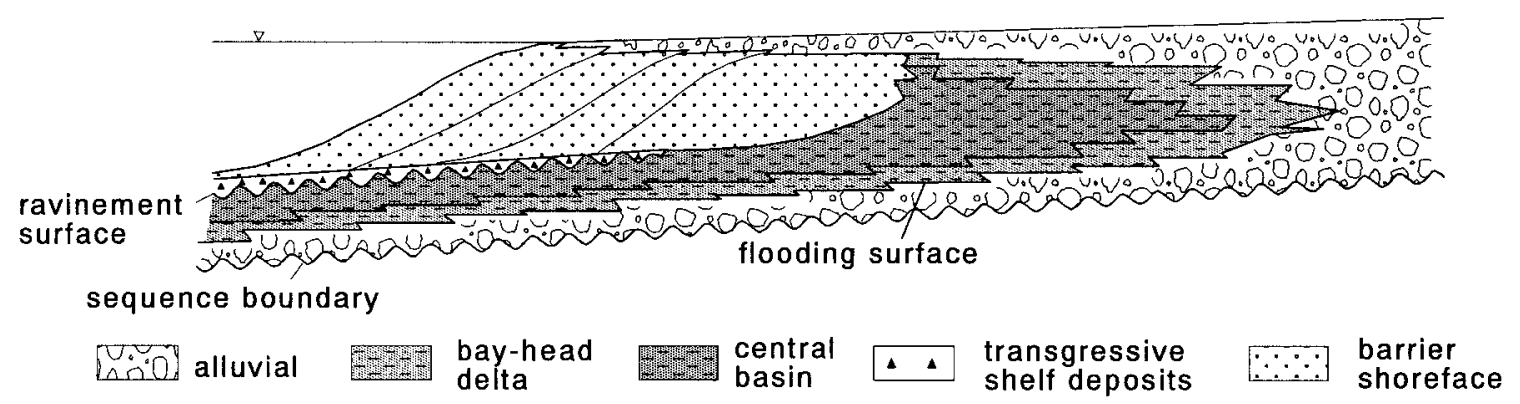

FIG. 1.-Dalrymple et al.'s (1992) facies model for wave-dominated estuaries.

was assessed with fifteen bathymetric charts of varying dates from the Directory of Hydrography at scales 1:2000, 1:5000, 1:10,000, and 1:15,000. It is worth noting that all information pertaining to the subsurface geology is restricted to an area $500 \mathrm{~m}$ wide. Therefore, most of the discussion presented in this study refers to the central axis of the estuary.

\section{REGIONAL SETTING}

\section{Sea-Level History}

Quaternary sea-level fluctuations in this part of the coast have been assessed by Bigarella (1946, 1971), Martin et al. (1988), Angulo (1992), Angulo and Suguio (1995), and Angulo and Lessa (1997). The elevation of the last two high sea levels, at about 120,000 and $5100 \mathrm{yr}$ BP, was +8 $\mathrm{m}( \pm 2.0 \mathrm{~m})$ and $+3.5 \mathrm{~m}( \pm 0.5 \mathrm{~m})$, respectively. Figure 4 presents a sea-level envelope with all the published samples dated in the region within the last 6200 years, which suggests a gradual fall of sea level after the postglacial maximum (see also Angulo and Lessa 1997).

The established sea-level behavior for the mid- to late Holocene in eastern Brazil (Suguio et al. 1985; Angulo and Lessa 1997) indicates that sea level overtook the present elevation by about $6500 \mathrm{yr}$ B.P. However, the position of sea level prior to $6500 \mathrm{yr}$ B.P., both in the study area and for the country as a whole, is difficult to assess, because no dates from subsurface or underwater samples exist.

\section{Geomorphology}

The two forced regressions following the sea-level maxima created two distinct geomorphologic zones: an upper zone (west of Paranaguá; Fig. 1) that constitutes an actual drowned, narrow, incised paleo-valley, and a lower zone (east of Paranaguá) that is characterized by wide beach-ridge plains (Angulo 1992; Lessa and Angulo 1995; Lessa and Angulo unpublished work). The latter was built during the last two falls of sea level, and have a maximum width of about $22 \mathrm{~km}$ (Fig. 2, inset) to the south of the estuary. Mel Island, located at the bay mouth, is part of a fragmented beach-ridge plain (Lessa and Angulo, unpublished work). Together with two coalescing ebb-tidal deltas offshore, the island shelters the internal parts of the bay from high-energy marine wave conditions.

On the basis of its morphologic and sedimentary characteristics, the Paranaguá Bay estuary shows a tripartite zonation similar to other barrier and coastal-plain estuaries (Dalrymple et al. 1992; Nichols et al. 1991; Allen and Posamentier 1993; Nichol et al. 1994). Figure 5 displays the three compartments: the meander zone, the estuary funnel, and the bay mouth. The bay-mouth zone is located in the lower part of the estuary, where the main channel is deeper than $10 \mathrm{~m}$ (maximum depth of $35 \mathrm{~m}$ in front of Ponta do Poço). It is surrounded by the beach-ridge plains, and the bottom sediments are characterized by well-sorted fine to very fine sand, with the content of fines $(<0.062 \mathrm{~mm}$ ) varying from $0 \%$ (seaward end) to $40 \%$ (landward end) (Fig. 6; Bigarella et al. 1978). The two biggest islands in the bay-mouth zone (Rasa and Cotinga Islands) are mostly made of emer- gent, shallow estuarine areas, largely covered with fossils of Anomalocardia brasiliana (Angulo 1992). Samples of A. brasiliana taken from surface deposits in Rasa Island were dated at $3480 \pm 70$ yr B.P., and indicate a paleo-sea level at least $+0.9 \mathrm{~m}$ above the present one (Angulo 1992).

The estuary funnel extends from Paranaguá to Antonina (Fig. 5) and has the widest cross sections of the estuary. Maximum depths are around 15 $\mathrm{m}$ in front of Paranaguá harbor, but generally vary between 10 and $4 \mathrm{~m}$, decreasing upstream. The shallower depths in this zone are a departure from the characteristic depth distribution in other wave-dominated estuaries, where the funnel zone (also called the central basin) is generally the deepest area (Roy 1984, 1994; Nichols et al. 1991; Dalrymple et al. 1992).

Despite some local exceptions, the bottom in the funnel zone is characterized by muddy sediments, with less than $50 \%$ sand (Fig. 6) (Bigarella et al. 1978). This section is within a better defined, linear drowned paleovalley, bordered by extensive tidal flats and mangrove swamps. The intertidal area is surrounded by relatively short sloping ramps of continental deposits and abruptly rising hillsides blanketed with colluvium, which reach elevations of up to $500 \mathrm{~m}$ within $5 \mathrm{~km}$ from the estuary. Bedrock crops out locally inside the estuary and along its borders. The estuary funnel zone narrows gradually upstream and, although not forming a perfect funnel (Fig. 5), a hypersynchronous situation appears to have developed (see below).

In the upper part of the funnel zone, in front of Antonina, elongated, non-vegetated, low-tide bars composed of shelly, dark mud curb navigation. Present-day bivalve species in soft substrates in the upper half of the estuary are Anomalocardia brasiliana (characteristic of euryhaline environments) and Crassostrea brasiliana, whereas Heleobia australis (characteristic of mesohaline and oligohaline environments) is the main gastropod species. The bars represent a bay-head delta typical of tide-dominated environments.

The meander zone accounts for the remaining $5 \mathrm{~km}$ of the estuary. It is the narrowest stretch of the estuary, with shallow channels $(<4 \mathrm{~m})$ where greater fluvial influence exists. The bottom sediments (Fig. 6) are mostly poorly sorted fine to medium sand, with less than $40 \%$ fines and frequently showing grain-size fractions larger than $2 \mathrm{~mm}$. Several low, although not intertidal, vegetated islands are observed in the seaward side of the meander zone. The islands are located by the exit point of several small rivers, and probably represent a riverine delta.

The infilling rate of the Paranaguá Bay estuary appears to have increased in the past decades. Apparently, a larger influx of fluvial sediments is causing an expansion of the tidal sand bars (bay-head delta) and the fluvial sand deposits at the head of the estuary. In the last 30 years, the tidal bars have grown and become more intertidal (Antonina Harbor Authority, personal communication 1995), probably because of the construction of a hydroelectric power plant and diversion of a neighboring catchment area towards Cachoeira River (Fig. 2). From a bathymetric chart from 1877 (Barão de Tefé 1877, in Soares and Lana 1994) for the Harbor of Antonina, there is an indication that the average depth in front of Antonina may have 


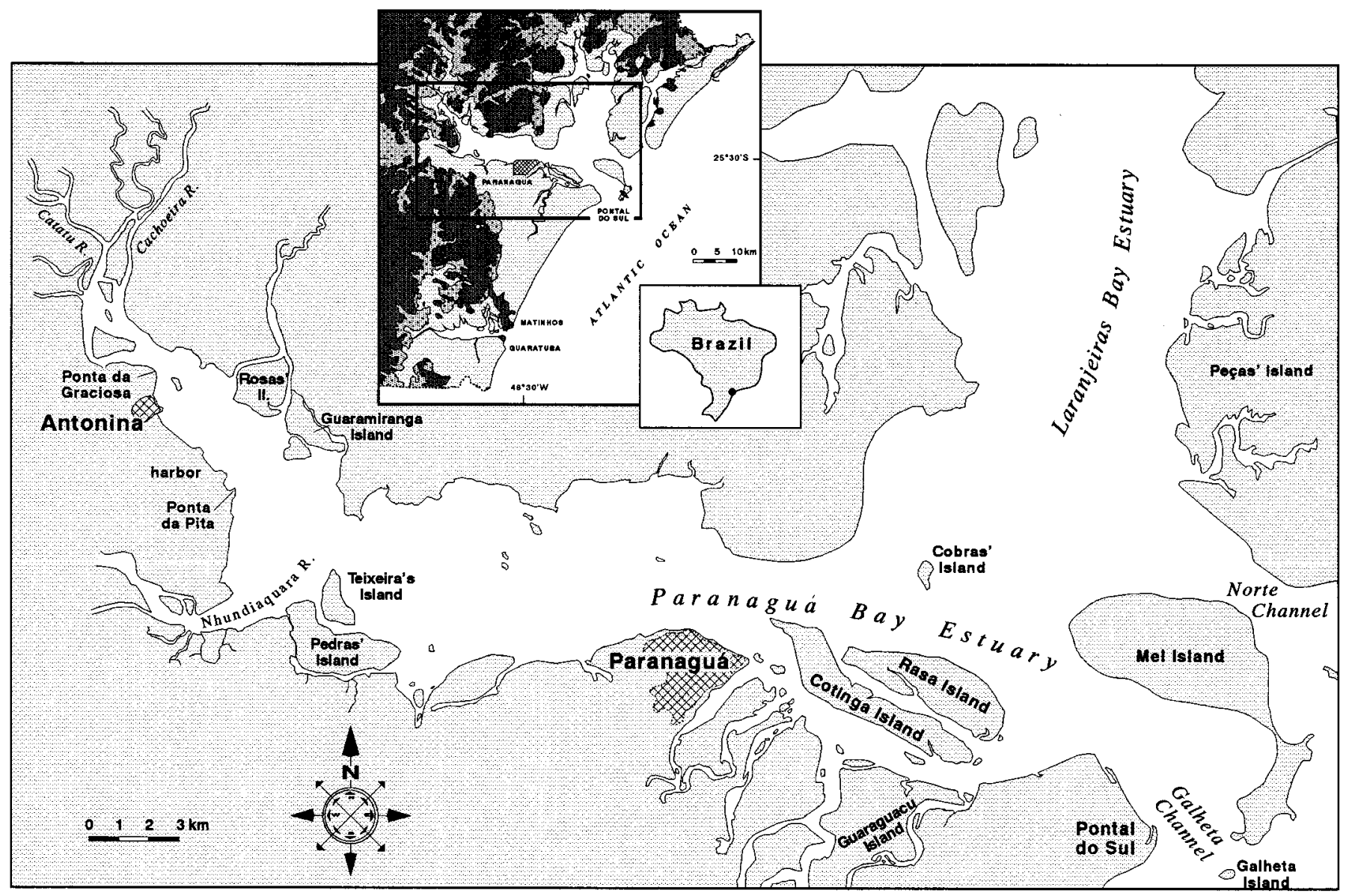

FIG. 2.-Location of the study area. The inset shows the Quaternary coastal plain (light gray), Quaternary continental deposits (hatched), and undifferentiated bedrock (dark gray).

shallowed at least $1 \mathrm{~m}$ since the survey was made. Also, a recent investigation of the surface sediment distribution showed a continuous strip of sandy sediments from the meandering zone to just downstream of Ponta da Pita (Fig. 2) (Soares et al. 1996). This implies some $4 \mathrm{~km}$ of progradation of the fluvial sand layer since the last sampling was performed 30 years ago (Bigarella et al. 1978) (Fig. 6).

\section{Hydrography}

The Paranaguá Bay estuary is fed by small, short, and steep drainage basins that descend from the Serra do Mar mountain complex. The Cachoeira River, at the head of the estuary, is the most voluminous, with an average discharge of $21.13 \mathrm{~m}^{3} / \mathrm{s}$, followed by the Nhundiaquara River, with an average discharge of $15.88 \mathrm{~m}^{3} / \mathrm{s}$ (Bigarella et al. 1978) (Fig. 2). The

TABLE 1.-Approximate mean time lags for spring (SL) and neap (NL) high and low tides (Galheta Channel, in the mouth of the Paranaguá Bay, is considered the zero time reference), and mean time of ebbing and flooding during spring tide (based on harmonic predictions). Mean spring and neap tidal ranges are also tabulated.

\begin{tabular}{|c|c|c|c|c|c|c|c|c|}
\hline \multirow[b]{2}{*}{ Location } & \multicolumn{2}{|c|}{ SL (min.) } & \multicolumn{2}{|c|}{ NL (min.) } & \multirow{2}{*}{$\begin{array}{l}\text { Flooding } \\
\text { Time } \\
\text { (hr.) }\end{array}$} & \multirow{2}{*}{$\begin{array}{l}\text { Ebbing } \\
\text { Time } \\
\text { (hr.) }\end{array}$} & \multirow{2}{*}{$\begin{array}{l}\text { Spring } \\
\text { Range }\end{array}$} & \multirow{2}{*}{$\begin{array}{l}\text { Neap } \\
\text { Range }\end{array}$} \\
\hline & high & low & high & low & & & & \\
\hline Galheta C. & 0 & 0 & 0 & 0 & 6.8 & 5.5 & 1.74 & 1.30 \\
\hline Cobras Il. & 69 & 55 & 91 & 75 & - & - & 2.07 & 1.68 \\
\hline Paranaguá & 88 & 68 & 106 & 93 & 7.5 & 4.8 & 2.09 & 1.70 \\
\hline Antonina & 100 & 110 & 132 & 151 & 8.1 & 4.2 & 2.74 & 2.02 \\
\hline
\end{tabular}

longest rivers are the Hhundiaquara and Cachoeira, with lengths in the order of $300 \mathrm{~km}$ and overall gradients of 1:15 between the water springs and the altitude of $40 \mathrm{~m}$ (given by Bigarella et al. 1978 as an arbitrary limit for the coastal plain).

The total catchment area of the Paranaguá Bay estuary is $1918 \mathrm{~km}^{2}$ (Maack 1968), and receives a mean annual rainfall of about $2500 \mathrm{~mm}$ (IPARDES 1990, 1991). However, precipitation can be as high as 5300 $\mathrm{mm} /$ year in the piedmont, where maximum rainfall of up to $230 \mathrm{~mm}$ in 24 hr has been recorded (Bigarella et al. 1978). High river gradients and rainfall result in the sand deposits characteristic of the river outlets in the estuary (Fig. 6).

The yearly average freshwater discharge to the bay has been estimated as $75 \mathrm{~m}^{3} / \mathrm{s}$ (Knoppers et al. 1987), taking into consideration the relative size of all other smaller streams that discharge into the estuary. However, recent field assessments of the fresh-water flow related to a few of the several smaller tributaries that were not previously investigated suggest that this value may be highly underestimated. More reasonable values would be close to $200 \mathrm{~m}^{3} / \mathrm{s}$.

\section{Oceanography}

Tide data are available for Galheta Channel, Cobras Island, and the harbors of Paranaguá and Antonina (see Figure 2 for location), where tide gauges were installed for periods of more than 2 months. Figure 7 shows two weeks of predicted astronomical tides for a spring-to-neap cycle at these four stations. The tides are mainly semidiurnal with diurnal inequalities. The tidal range is enhanced upstream, especially during spring tides 

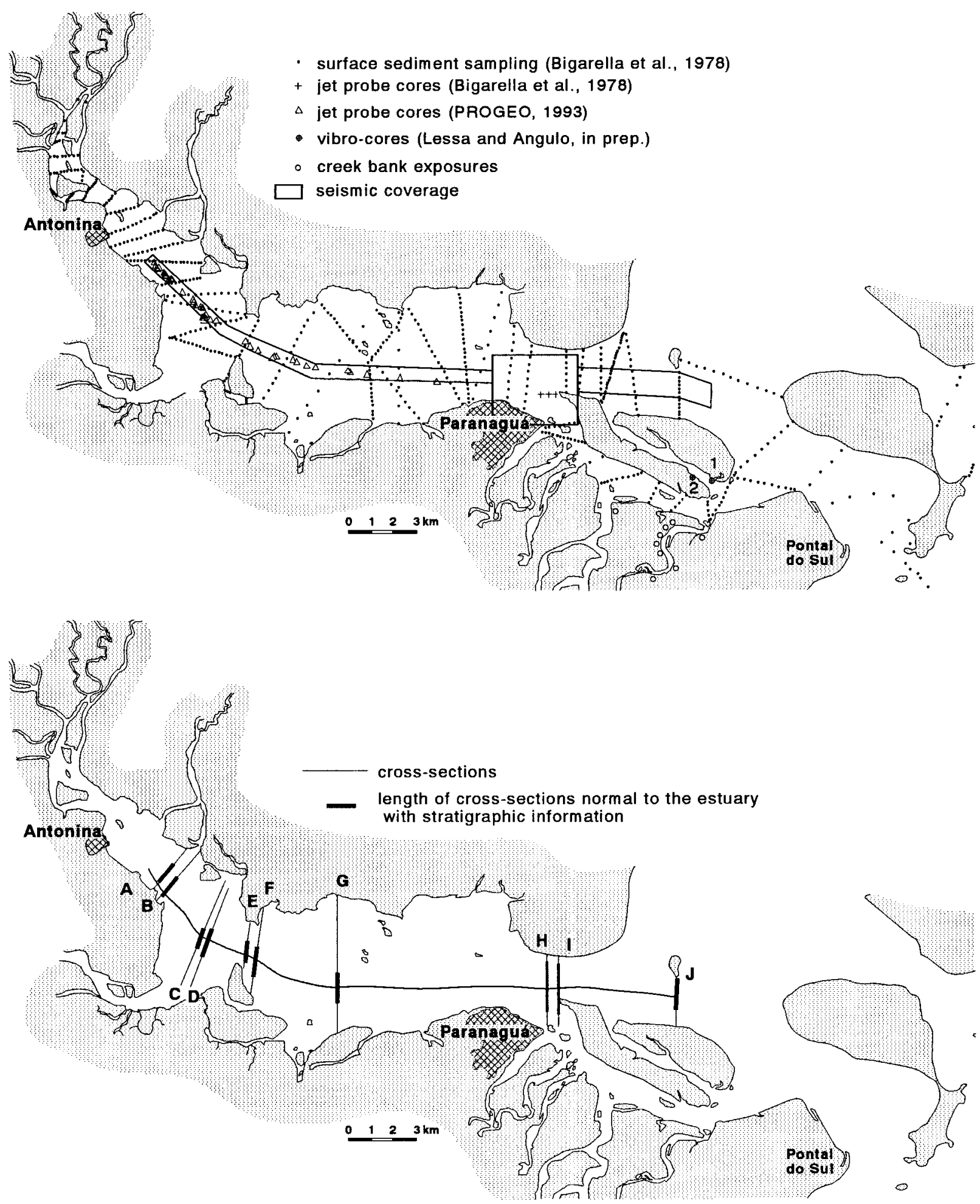

FIG. 3.-A) Location of the surface sediment samples, jet-probe cores used to construct the cross sections, and area covered by the seismic data, and B) location of the normal and longitudinal stratigraphic cross sections.

(Table 1), when it varies from $1.7 \mathrm{~m}$ in the entrance to nearly $2.7 \mathrm{~m}$ in Antonina. During neap tides, the tidal range is reduced to less than $80 \%$ of the spring tidal range, and strong nonlinear interaction between the tidal constituents allows for the formation of up to 6 high and low tides per day (Marone and Camargo 1994). The tides also display an increasing asym- metry upstream, characterized by a shorter falling and a longer rising tide. The average ratio of flooding to ebbing time increases from 1.23 at Galheta Channel to 1.92 close at Antonina (Table 1).

The asymmetry of the astronomical tide inside estuaries has been shown to cause the predominance of one direction of tidal flow (flood or ebb) 


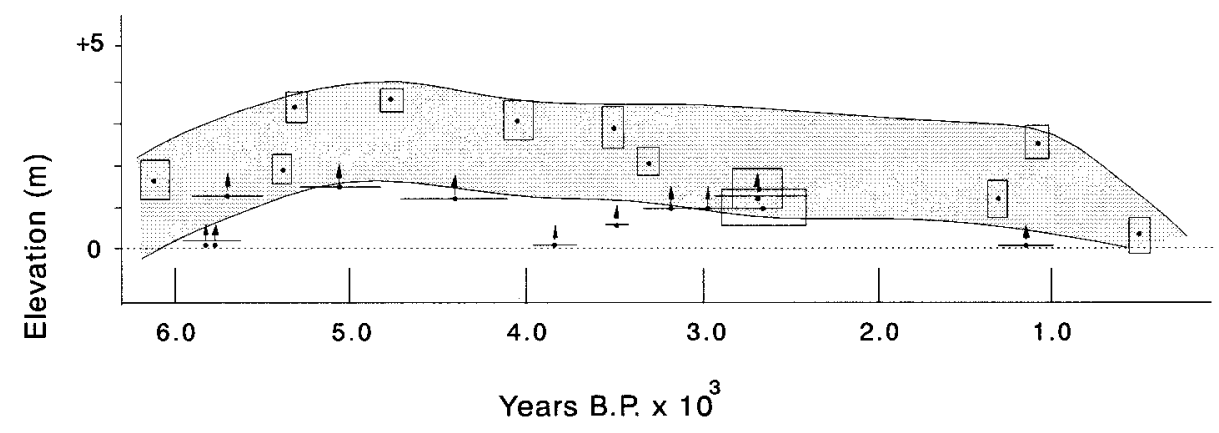

FIG. 4.-Sea-level envelope for the last 6000 $\mathrm{yr}$ in the study region, based on the reevaluation of sea-level data from Angulo and Lessa (1997). over the other (Friedrichs and Aubrey 1988), and consequently a net nearbed sediment transport direction (Fry and Aubrey 1990). The observed asymmetry of the tidal wave in Paranguá estuary would be characteristic of an ebb dominance of the tidal flow and ebb-directed net sediment transport. Figure 8 shows the average current velocity in two vertical profiles (not simultaneous) in cross sections in front of Antonina and Paranaguá. Ebb velocities are faster than flood velocities in both cases. There is also a lateral stratification of the flow at the turn of the tides in Antonina, with water flowing out close to both of the margins while still flowing in through the middle of the channel. Studies conducted by the Brazilian Navy (IPqM 1969) in three cross sections of the navigation channel also showed residual currents between 0.09 and $0.05 \mathrm{~m} / \mathrm{s}$ with opposite directions, suggesting the presence of meandering flood and ebb channels. Lateral inhomogeneity of flow was also indicated by Knoppers et al. (1987) with salinity data. Marone and Jamiyanaa (1998) performed current-velocity profiling in four cross sections (two near Antonina, one close to Paranaguá and one in Galheta Channel) and identified flood and ebb channels upstream from Paranaguá. Average maximum current velocities at Galheta Channel, Paranaguá, and Antonina were $0.90 \mathrm{~m} / \mathrm{s}, 1.10 \mathrm{~m} / \mathrm{s}$, and $1.00 \mathrm{~m} / \mathrm{s}$, respectively, all ebb directed. The current velocity appears to increase upstream, which, along with larger tidal ranges, would make the estuary hypersynchronous.

The tidal prism in different sections of the bay can be assessed by multiplying their cumulative surface area (Table 2) by the spring tidal range. If divided by the period of half of a tidal cycle, the average spring-tide discharge in the three morphological zones can be assessed (Table 2). The fluvial discharge into the bay seems to be only about $4.6 \%$ of the spring tidal discharge at the seaward end of the meandering zone close to Antonina. This points out how important the tidal flow is to sedimentation along the estuary during average flow conditions.

\section{RESULTS}

\section{Vibracore Data}

Vibracores \#1 and \#2 (Fig. 3) were $6.0 \mathrm{~m}$ and $5.90 \mathrm{~m}$ long, respectively. Both showed strongly laminated deposits, with sand laminae varying from

TABLE 2.-Physical characterization of the morphological zones. The surface area given is cumulative from the head of the estuary. The depths for separate sections were estimated from the nautical charts (Knoppers et al. 1987), and tidal discharges are estimated at spring tide conditions.

\begin{tabular}{lccccc}
\hline \hline \multicolumn{1}{c}{ Site } & $\begin{array}{c}\text { Surface } \\
\text { Area } \\
\left(\mathrm{km}^{2}\right)\end{array}$ & $\begin{array}{c}\text { Mean Depth } \\
(\mathrm{m})\end{array}$ & $\begin{array}{c}\text { Maximum } \\
\text { Depth } \\
(\mathrm{m})\end{array}$ & $\begin{array}{c}\text { Tidal } \\
\text { Discharge } \\
\left(\mathrm{m}^{3} / \mathrm{s}\right)\end{array}$ & $\begin{array}{c}\text { Fluvial/ } \\
\text { Tidal } \\
\text { Discharge }\end{array}$ \\
\hline $\begin{array}{l}\text { Meandering zone } \\
\text { Estuary funnel }\end{array}$ & 35 & 1.9 & 8 & 4296 & 0.046 \\
$\quad \begin{array}{l}\text { zone } \\
\text { Bay-mouth zone }\end{array}$ & 117 & 4.3 & 17 & 10903 & 0.018 \\
\hline
\end{tabular}

less than $0.1 \mathrm{~cm}$ to around $1 \mathrm{~cm}$, in some cases reaching more than $5 \mathrm{~cm}$. The variation in the thickness of the sand laminae is gradual and gradational, in a pattern that resembles tidal bundles (spring-neap tidal cycles). Most of the laminae, especially in vibracore \#1, were highly bioturbated. The deepest $1.5 \mathrm{~m}$ of vibracore \#1 shows a change in the sediment texture, with the mud having been replaced by shells and shell fragments, with a large content deriving from open-marine bivalves and gastropods (Dosinia concentrica, Crassinela lunata, Calyptrea centralis, and Natica sp., amongst others).

\section{Seismic Interpretation}

The interpretation of the seismic data is given in the 20 unpublished seismic charts and two unpublished technical reports (ENCAL 1972; Companhia Brasileria de Dragagem 1980). Three seismic horizons were always identified in the documents (Fig. 9), along with a level of no acoustic penetration. The first horizon (F.H.) corresponds to the present-day floor of the bay, and the second horizon (S.H.) identifies the top of a compact muddy sand (Companhia Brasileira de Dragagem 1980) that is associated with the Alexandra Formation, described below.

The aforementioned technical reports indicate that the third horizon (T.H.) of the seismic data identifies bedrock, either outcropping or under sedimentary cover. In theory, the level of no acoustic penetration (N.P.) represents the maximum depth of penetration of the sound waves sometime prior to encountering the S.H. or T.H.. The sound wave reflection is total, and does not allow an absolute textural differentiation (Companhia Brasileira de Dragagem 1980). Depending on the topography of the record, the N.P. was interpreted as bedrock (rough surface contour) or as sediment layers consisting of oyster shells and organic mud (smooth surface contour) (Companhia Brasileira de Dragagem 1980). Dredging operations close to the Paranaguá Harbor allowed correlation of the N.P. with oyster shells in organic muds (ENCA 1972).

The only existing wells in this investigation with the potential for a more detailed correlation with the seismic data and the well sediment descriptions are those given described by Bigarella et al. (1978), which come from an area close to Paranaguá harbor (Figs. 3, 10). The information from the logs show at least three distinctive sedimentary units: an upper sandy unit, a muddy unit, and a lower coarse-sand/gravelly unit (Fig. 10). In half of the wells, it was possible to check the good correlation between the depth of a poorly sorted, relatively compact, muddy-sand deposit, and the depth of the S.H. in the seismic sections (varying between $13 \mathrm{~m}$ and $25 \mathrm{~m}$ ). In the area where the other half of the cores are located, the N.P. zone was identified. This zone, however, was located in a much shallower depth $(-7 \mathrm{~m})$ than that of the organic mud deposits (Fig. 10) that would be associated with the N.P. zone.

The cores shown in Figure 10 come from a shallow area sheltered by the islands and the harbor, with mangroves nearby. In such a scenario, fines 

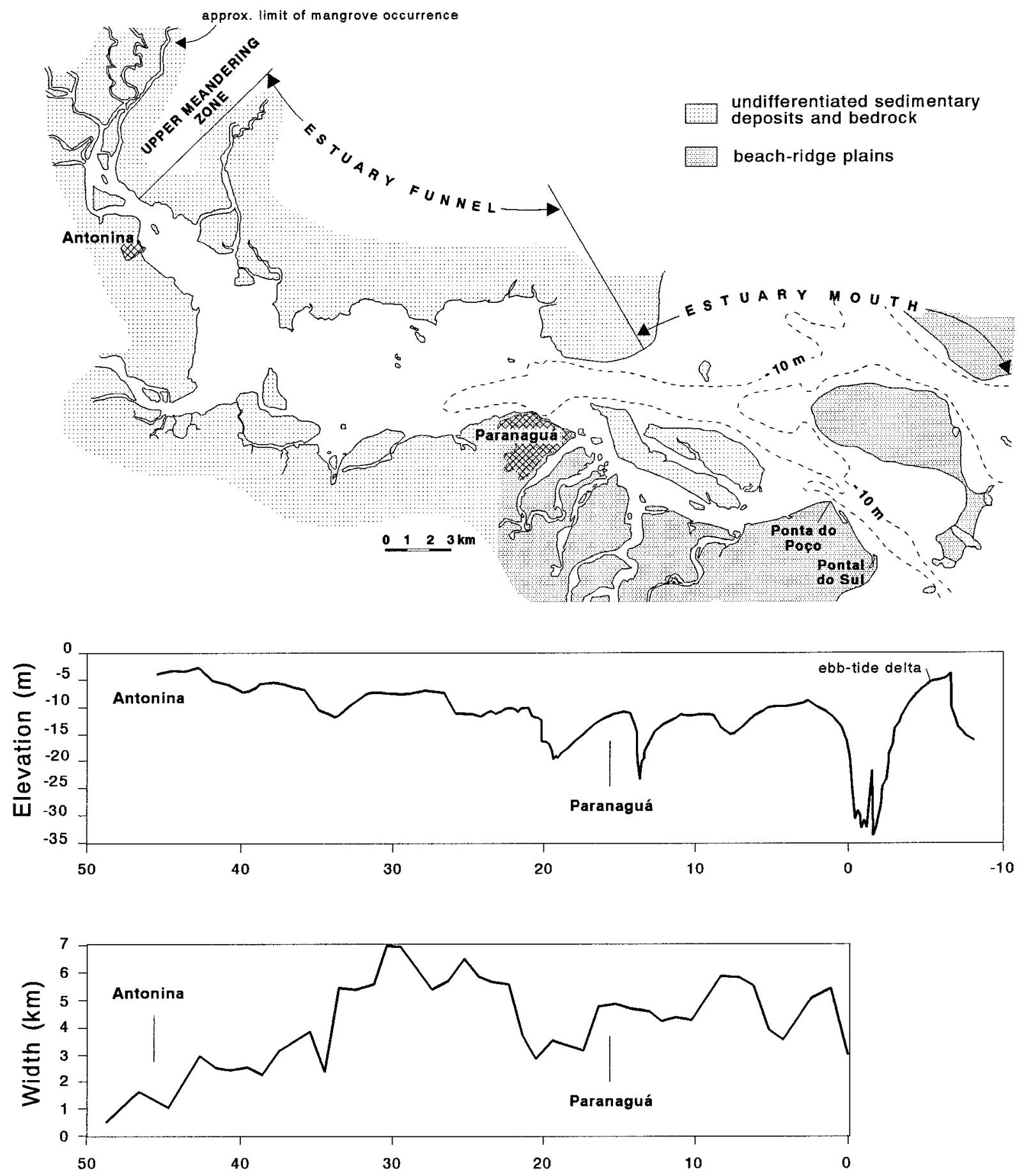

FIG. 5.-Estuary tripartite zonation and graphs showing the width and depth (of the central axis) variation along the estuary.

and organics may have been deposited along with sand (see the relatively high quantities of mud in some points in the upper half of the cores; Fig. 10). In fact, mud/sand laminae are observed in similar environments close to Cotinga Island (vibracores \#1 and \#2, Fig. 3). The possible existence of extensive organic-mud laminae within the transgressive sand may have caused a shallower depth indication of the N.P. zone close to these wells. Although the same problem is likely to occur in other sheltered areas within the estuary, we will assume that the N.P. depth is correlative with the top surface of an organic-rich mud layer anywhere along the main channel, where higher flow velocities occur. We believe that extensive organic-mud laminae are inhibited in such dynamic environs (see Oceanography section), and that a transgressive organic-mud layer (as in Figure 10) should be regionally preserved beneath the transgressive sand, as will be shown below.

\section{Sedimentary Facies}

Five distinctive sedimentary facies overlying the bedrock were identified within the incised-valley fill of the Paranaguá Bay estuary. These sedimentary facies are displayed in cross sections normal and longitudinal to 


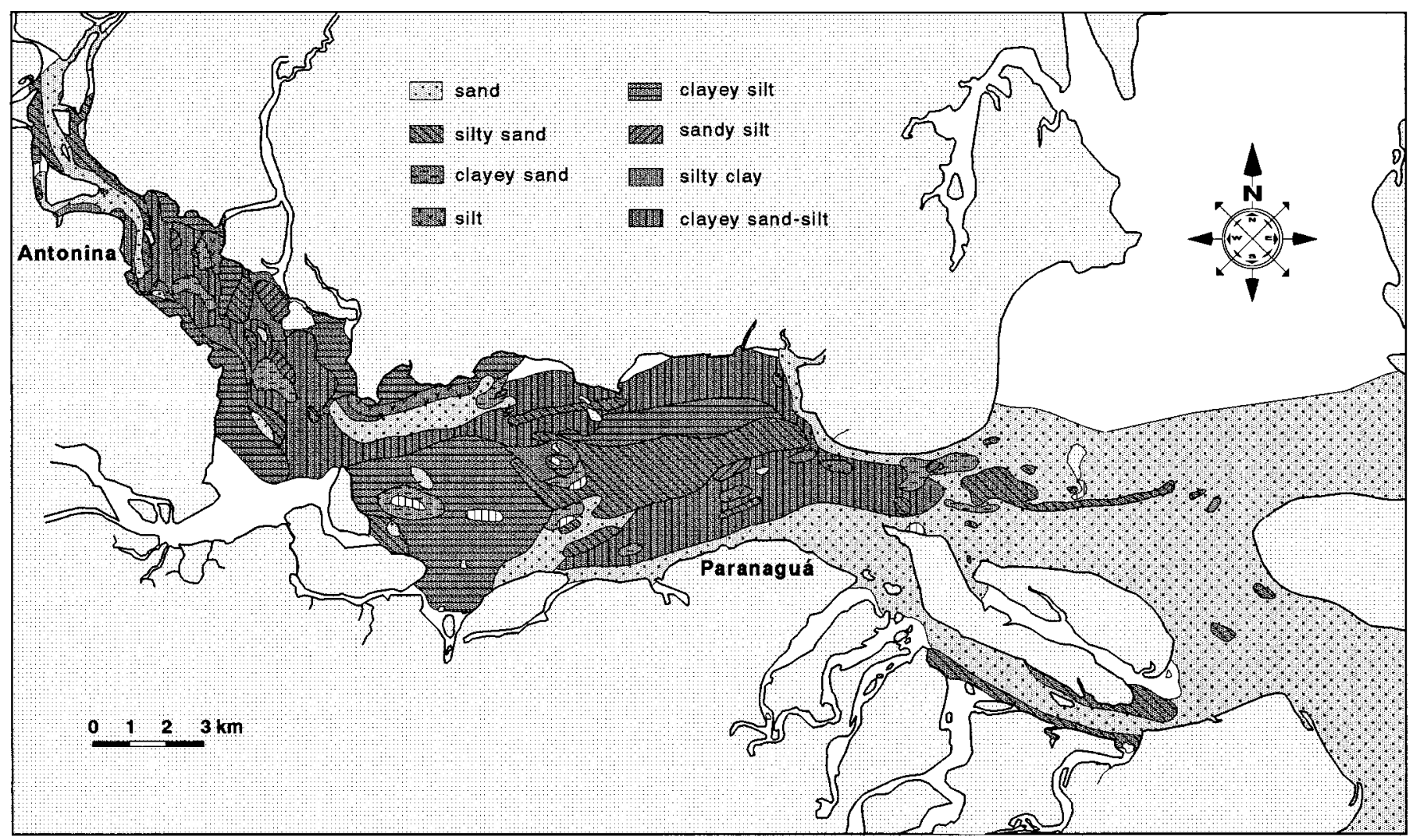

Fig. 6.-Textural surface sediment distribution in the Paranaguá Bay estuary (after Bigarella et al. 1978).

the estuary axis (Figs. 11-13). From older to younger, these sedimentary facies can be described as follows:

(1) Pre-Holocene Fluvial and Continental Deposits: These deposits are present along the whole estuary, and in most of the paleo-valley they constitute the substrate for the more recent sedimentation. This facies appears to fill the paleo-valley carved in the bedrock (cross sections $\mathrm{H}$ and $\mathrm{I}$ in Figure 12; Figure 13) with a thickness of up to $20 \mathrm{~m}$. The pre-Holocene fluvial and continental deposits were identified by Bigarella (1978) (Fig. 10) as the Alexandra Formation as well as its reworked material. Outcrops of the Alexandra Formation around Paranaguá Bay are suggested to be of Miocene age (based on paleontological data) and comprises a succession of arkosic sands and mud layers, and with minor gravel (Angulo 1995). The color varies between grayish green and orange. This formation has been interpreted as mass-flow deposits (Angulo 1995) that overlie the crystalline and weathered bedrock.

The reworked Alexandra sediments suggested by Bigarella et al. (1978), differentiated by a lesser amount of silt and clay, may be correlated to younger alluvial-fan deposits of Plio-Pleistocene age that extensively abut the coastal plain close to the mountains (Angulo 1995). The thickness of the reworked Alexandra sediments is around $4 \mathrm{~m}$ in the only core that completely penetrated the unit (Bigarella et al. 1978). The sediments in these deposits are mostly gravel, pebbles, and boulders within a sandyclayey matrix.

(2) Transgressive Mud Facies: The transgressive mud facies is typified by a dark-gray mud with high organic content. This facies is composed of more than $80 \%$ fines $(<0.062 \mathrm{~mm})$, with a small fine sand component and fragments of shells. Facies 2 is generally found underlying the transgressive sand facies (Facies 3) and overlying the pre-Holocene fluvial and continental deposits (Facies 1) or locally the bedrock (cross sections H, I, and $\mathrm{J}$ in Figure 12; Figure 13). There is no indication of the presence of the transgressive mud facies anywhere west of Paranaguá. Its absence could be related to erosion caused by more intense tidal ravinement caused by smaller cross-sectional areas and stronger flow velocities, and possibly associated with a thinner deposit due to smaller accommodation space. The transgressive mud facies thickens seaward, attaining about $20 \mathrm{~m}$ east of Cobras Island (Fig. 13). It has been found outcropping on the channel bed behind Mel Island (Soares et al., unpublished work), and may also be related to the patches of muddy sediments observed in Figure 6 in the area between Cobras, Rasa, and Mel Islands, where channel scouring has opened "stratigraphic windows" (cross section J, Figure 12). In addition, this unit is likely related to organic mud deposits, of Holocene age, found underneath the barrier deposits that border the lower half of the estuary (Lessa and Angulo 1995; Lessa and Angulo, unpublished work). It is proposed that this deposit was formed during a lower sea level (because they underlie a sand facies characteristic of transgression), perhaps already in the Holocene, in a low-energy environment associated with either the confines of the estuary funnel or the estuary margins. As such, it would be an analog of the currently prograding regressive mud facies (Facies 4).

(3) Transgressive Sand Facies: This unit comprises well to moderately sorted fine to very coarse sand, with rounded to subangular grains and values of mean grain size and sorting commonly about $0.4 \mathrm{~mm}$ and 0.1 $\mathrm{mm}$, respectively. The proportion of fines varies between $0 \%$ (seaward end) and 39\% (landward end), with a mean around $15 \%$. The carbonate content (shell fragments) is on average 3\% but can locally reach as much as $25 \%$. Wood fragments are also present in the sediments. The sediment color is variations of gray due to differing degrees of organic content. However, the organic content does not appear to exceed $4 \%$. In the lower reaches of the estuary (east of Paranaguá) this unit overlies either the transgressive mud facies (Facies 2) (cross sections H, I, and J in Figure 12; Figure 13) or lies directly upon the pre-Holocene fluvial and continental deposits (Facies 1) in locations where Facies 2 has been completely scoured (cross sections C, D, and E in Figure 11; cross sections F, H, I and J in Figure 

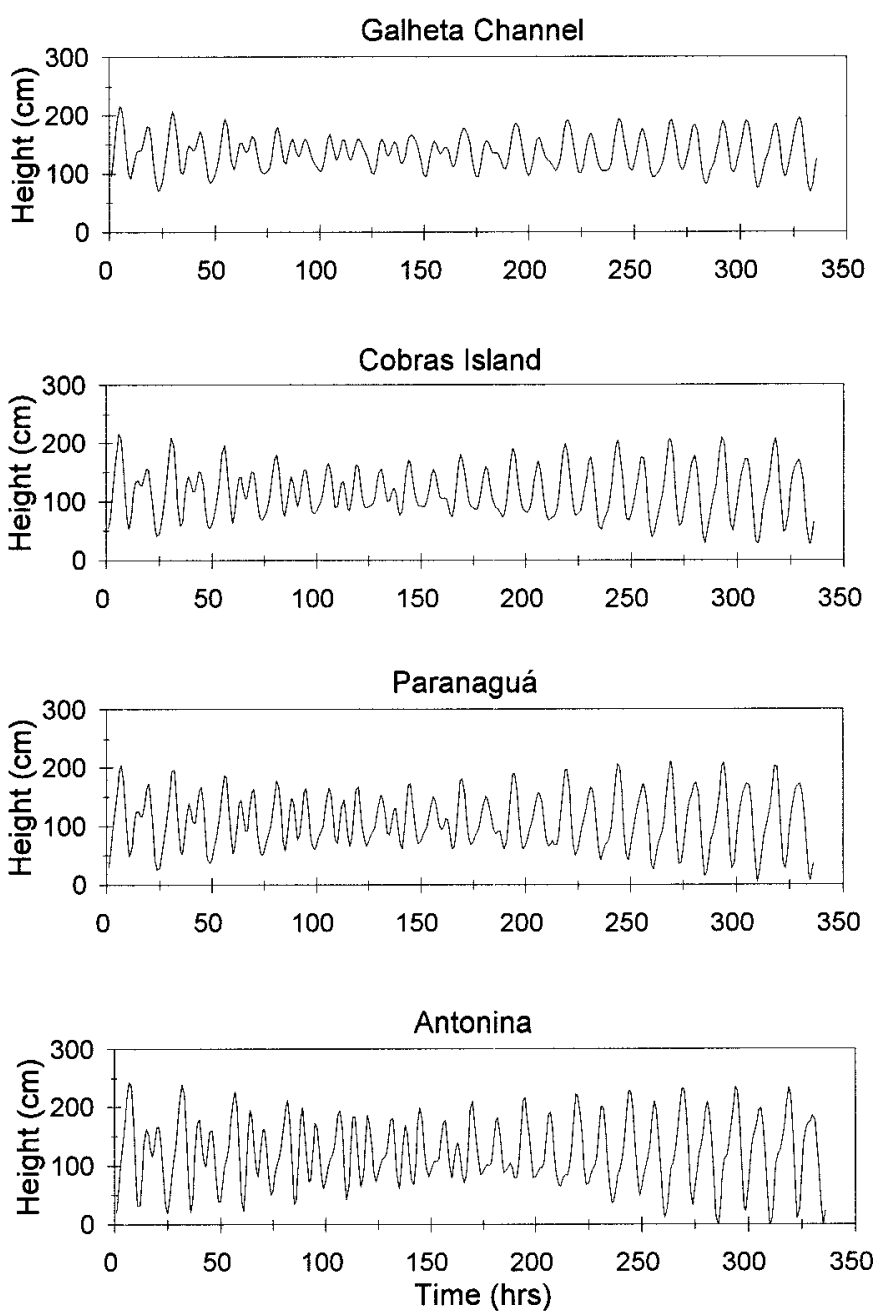

FIG. 7.-Tidal records at four locations along the estuary based on harmonic predictions (see Figure 2 for location).

12; Figure 13). In either case the contact between the transgressive sand facies and the underlying facies is likely to be erosional. Landward of Paranaguá the transgressive sand facies appears to everywhere overlie Facies 1 . Throughout much of the estuary the transgressive sand facies is overlain by the regressive mud facies (Facies 4) (cross sections C, D, and $\mathrm{E}$ in Figure 11; cross sections $\mathrm{H}$ and $\mathrm{I}$ in Figure 12; Figure 13).

This deposit is interpreted as a transgressive marine sand derived from the shoreface, and perhaps from some remobilization of scoured older deposits (Facies 1). Some of the sediments ascribed to the transgressive sand facies in the proximal part of the estuary may actually be fluvial sand (perhaps within a river channel, as in cross section A in Figure 11). Roundness of the sand grains indicates that reworking of older fluvial deposits (of pre-Holocene age) might have occurred. Because of the method of sediment recovery (jet probe) and the intense erosive forces related to tidal ravinement, the distinction between fluvial and tidally reworked fluvial deposits may be difficult. Although there are no dates indicating a depositional chronology, it is proposed that the deposit is associated with a complete drowning of the estuary in the time span between 7000 and $5100 \mathrm{yr}$ B.P., as sea level may have overtaken the present msl for the first time at about 6300 yr ago (Suguio et al. 1985).

(4) Regressive Mud Facies: An organic-rich sandy mud with shell fragments nearly covers the entire estuary upstream from Paranaguá (Fig. 6; cross sections A to E in Figure 11; cross sections F, G, H, and I in Figure
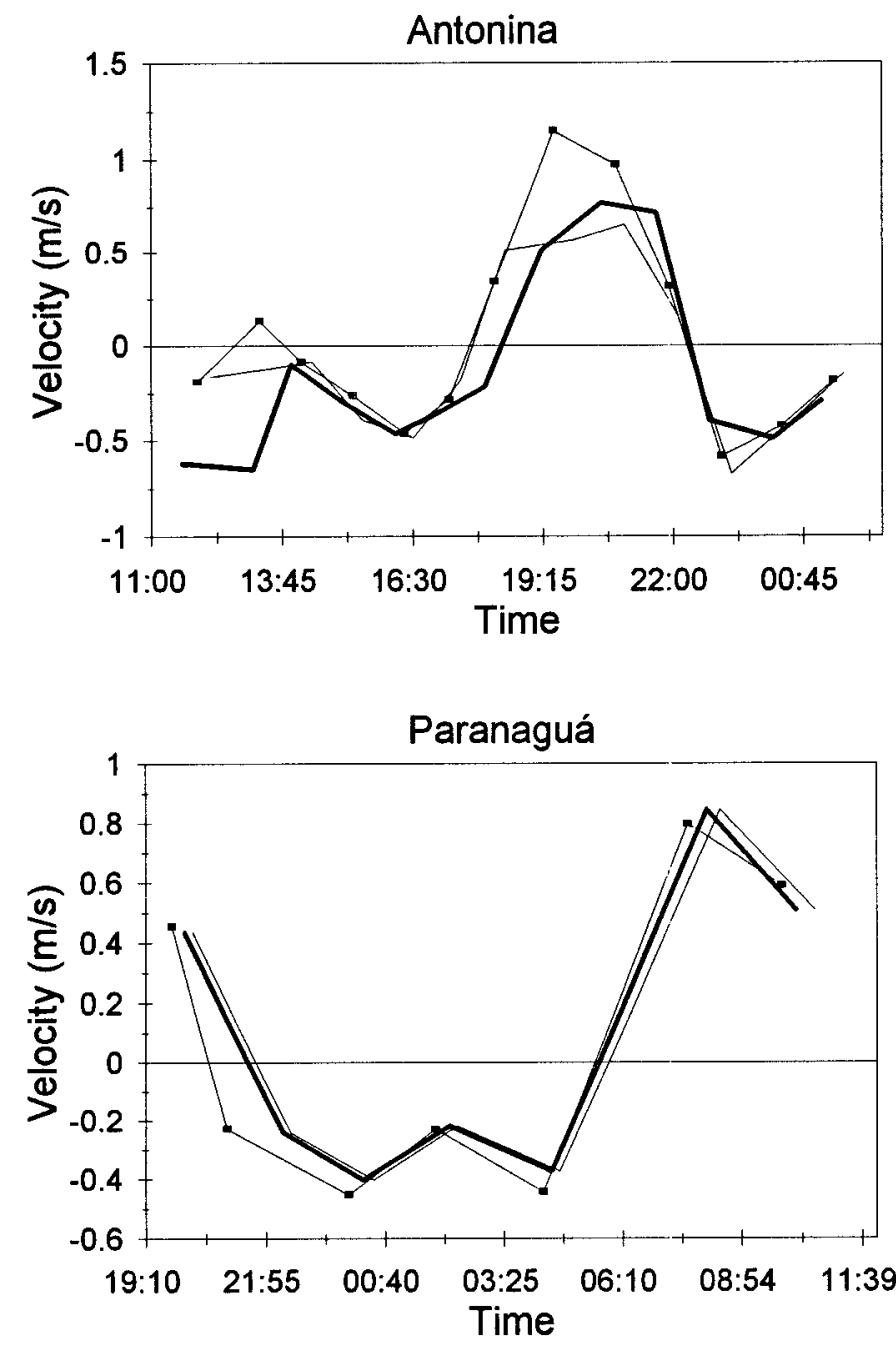

- left margin - mid-channel - right margin

FIG. 8.-Velocity pattern in two cross sections in the beginning of the ebbing tide through the succeeding flooding spring tide in a cross-section close to A) Antonina and B) Paranaguá, respectively. Ebb velocities are positive and flood velocities are negative.

12; Figure 13). The organic content of the sediments ranges from $2.2 \%$ to $20 \%$, whereas the content of fines varies between $30 \%$ and $91 \%$, with values above $70 \%$ being more common. Figure 6 provides a good representation of the surface textural variation of this facies. The relative amount of carbonate in the sediments is around 15\%, although it was observed in the field that this figure can be much higher along the linear tidal ridges (bay-head delta) close to Antonina. The unit rests conformably on the transgressive sand facies (Facies 3), and only locally is found covering bedrock (cross sections A and B in Figure 11; Figure 13). Maximum observed thickness of the regressive mud facies occurs upstream of Teixeira's Island (Fig. 13), where it is over $10 \mathrm{~m}$ thick. It appears that this unit fines upwards along with an increasingly larger concentration of shells and organics, which would reflect a gradual decrease in the energy level of the tidal currents through time. This deposit has been interpreted as an estuarine regressive mud facies, laid down along the funnel estuarine section, and associated with the sea-level fall of the last $5100 \mathrm{yr}$. As stated above, it should be an analog for the transgressive mud facies (Facies 2) found in the lower half of the estuary. 


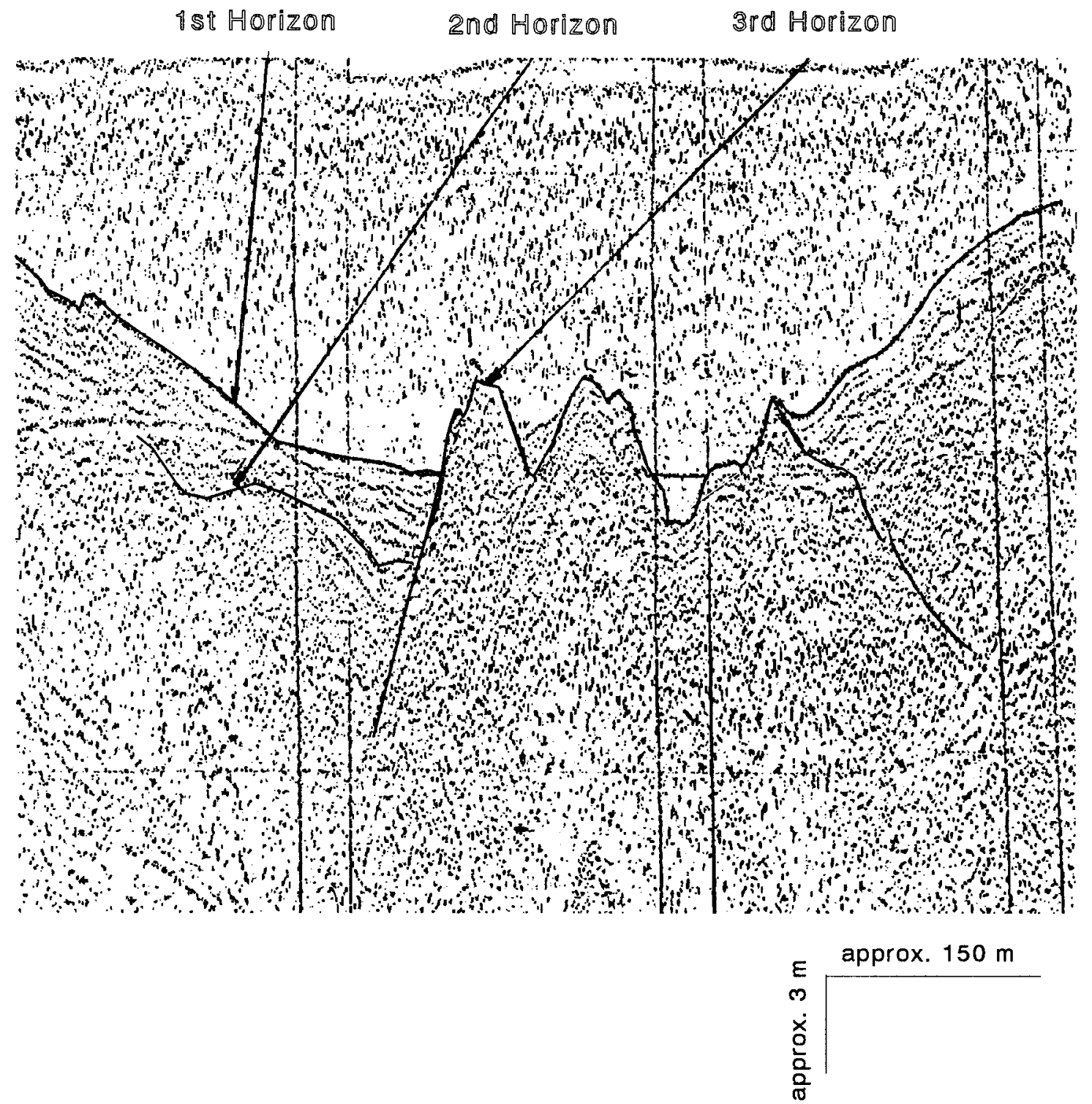

FIG. 9.-Seismic record normal to the estuary axis near cross sections E and F (see Figure 3 for location).

(5) Regressive Sand Facies: An areally restricted, moderately to poorly sorted sand layer is observed close to the head of the estuary, upstream from Antonina (Fig. 6). Average mean and sorting are 0.23-1.8 $\mathrm{mm}$ and $0.15-2.4 \mathrm{~mm}$, respectively. The color is grayish, and the fines content in the sediments range from $9 \%$ to $35 \%$, with an average value of $22 \%$. This unit may overlie the regressive mud facies (Facies 4) with a possible erosional contact, although there is no coring data from this zone of the estuary to support this conjecture. This facies has been interpreted as a recent fluvial deposit.

\section{DISCUSSION}

\section{The Estuarine Facies within a Sequence Stratigraphic Framework}

A type 1 Sequence Boundary (SB) is located within the pre-Holocene fluvial and continental deposits (Facies 1), where any upper Pleistocene fluvial sand (not yet documented) overlies the intact Alexandra Formation, or in the contact between the Alexandra Formation and Facies 2 and 3 (when upper Pleistocene fluvial sediments were eroded or not yet deposited; see also Allen and Posamentier 1993).
Although difficult to document with the existing data, a lowstand system tract (LST 1) is interpreted to exist where reworked sediments of the Alexandra Formation and fluvial sand are still intact beneath Facies 2, 3, and 4. Erosion may have locally removed the sediments related to LST 1, but it is also possible that lack of relevant data points has prevented location of these sediments.

The first bounding surface above the LST 1 is the transgressive surface (TS) (Fig. 14A, B), which may amalgamate with the transgressive tidal ravinement surface (TTR) (Fig. $14 \mathrm{~A}-\mathrm{C}$ ), the wave ravinement surface (WR) (in the first quarter of the estuary, which falls outside the study area), and the SB in parts of the estuary. The TS is defined as the flooding surface separating the progradational or aggradational LST 1 from the retrogradational TST (Van Wagoner et al. 1988). This transgressive surface may lie within the basal fluvial deposits, especially in cases where these deposits are relatively thick (Zaitlin et al. 1994; Nichol et al. 1994). In the Paranaguá Bay estuary, however, the TS seems to coincide with the initial flooding surface, i.e., the estuarine/fluvial contact. This appears to occur in incised valleys where little fluvial sediment is being deposited at the head of the estuary (Allen and Posamentier 1993, 1994; Nichol et al. 1994). The max- 


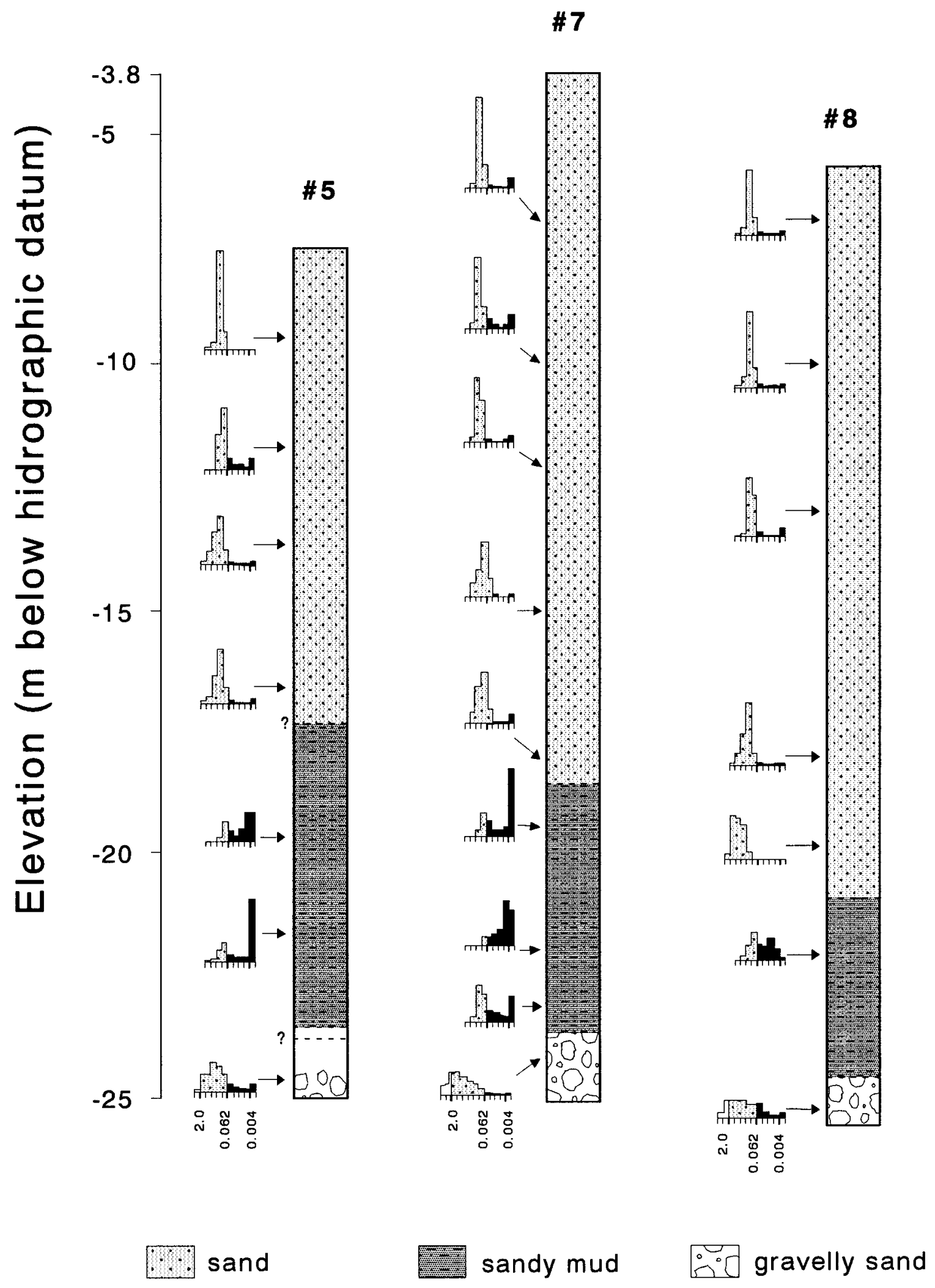

FIg. 10.-Well logs adjacent to Paranaguá Harbor (after Bigarella et al. 1978) (see Figure 3 for location). Hydrographic datum is $0.85 \mathrm{~m}$ below mean sea level, and scale of minimized graphs are in millimeters. 


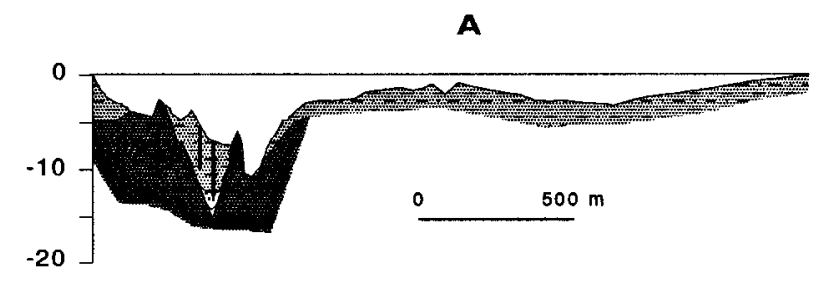

B
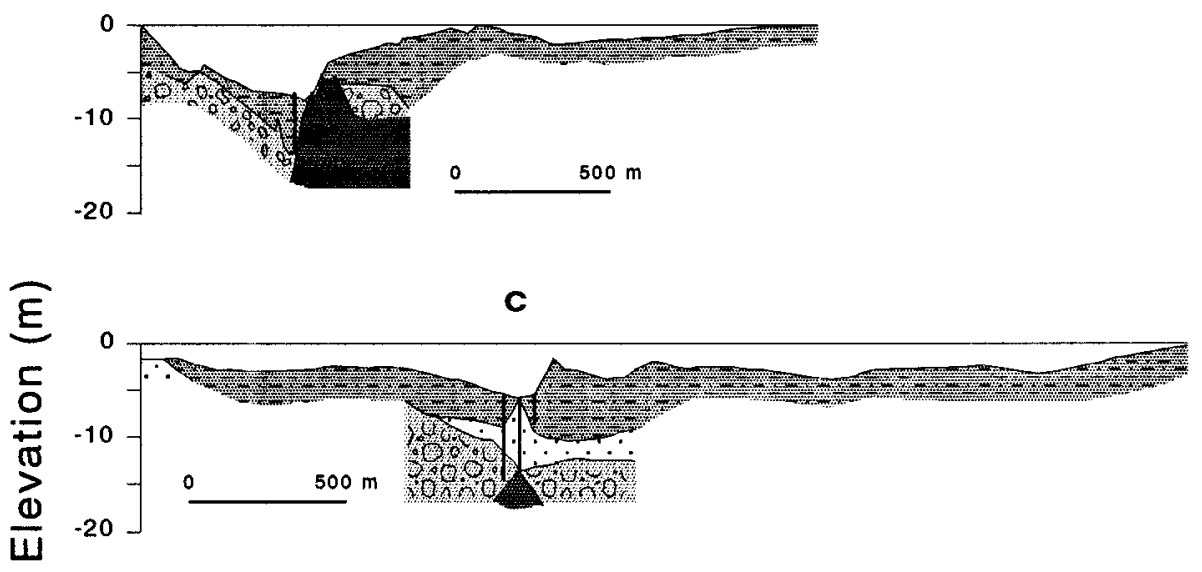

D
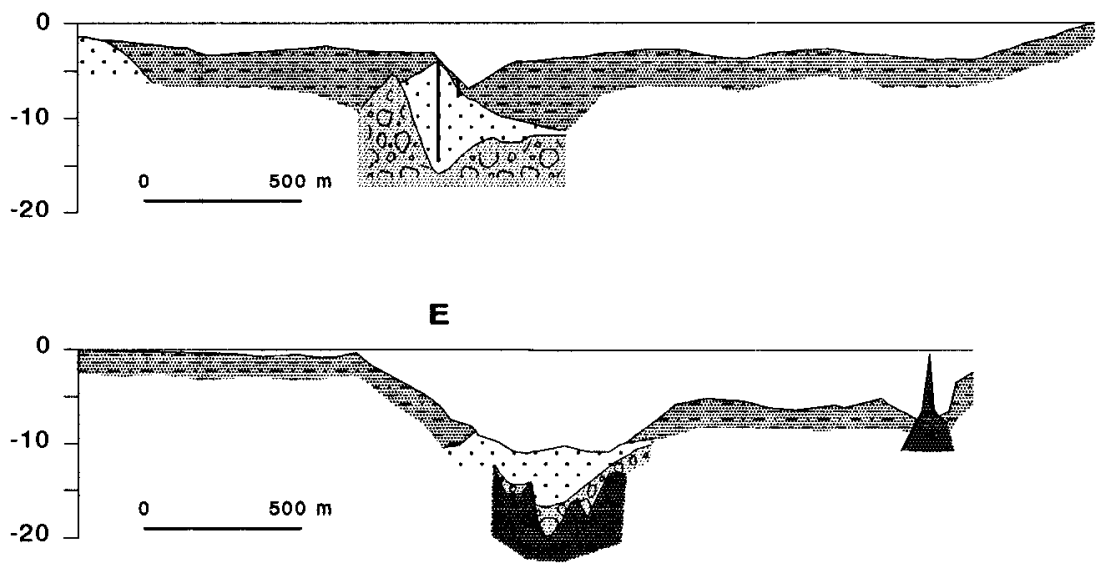

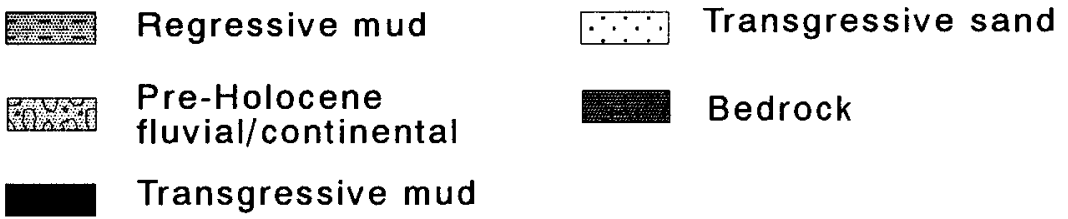

Fig. 11.-Stratigraphic cross sections normal to the estuary axis. See Figure 3 for location of the cross sections. imum identified thickness of the pre-Holocene sediments (Facies 1) in the Paranaguá Bay estuary is $15-20 \mathrm{~m}$, and only a small fraction of this is likely to represent fluvial deposits.

Following the formation of the TS, a transgressive system tract (TST) developed, which lies directly above the TS. The transgressive mud facies (Facies 2) and the transgressive sand facies (Facies 3) (Fig. 14B, C) are components of the TST. As with the Gironde estuary (Allen and Posamentier 1993), the presence of the transgressive mud facies overlying the pre-Holocene fluvial and continental deposits in the Paranaguá Bay estuary indicates "that the Holocene eustatic rise was sufficiently rapid [or sedimentation sufficiently slow] that the increased accommodation [for the transgressing sediment] was greater than the fluvial sediment influx."

The TST components are separated by the TTR. The TTR formed in parts of the estuary during onlap of the transgressive sand facies of the TST, and is believed to have resulted in complete erosion of the transgressive mud facies in parts of the estuary, especially in its upper half, where narrowing of the channel allowed for faster flow (Fig. 14A). The TTR is also likely responsible for removal of Pre-Holocene sediments 

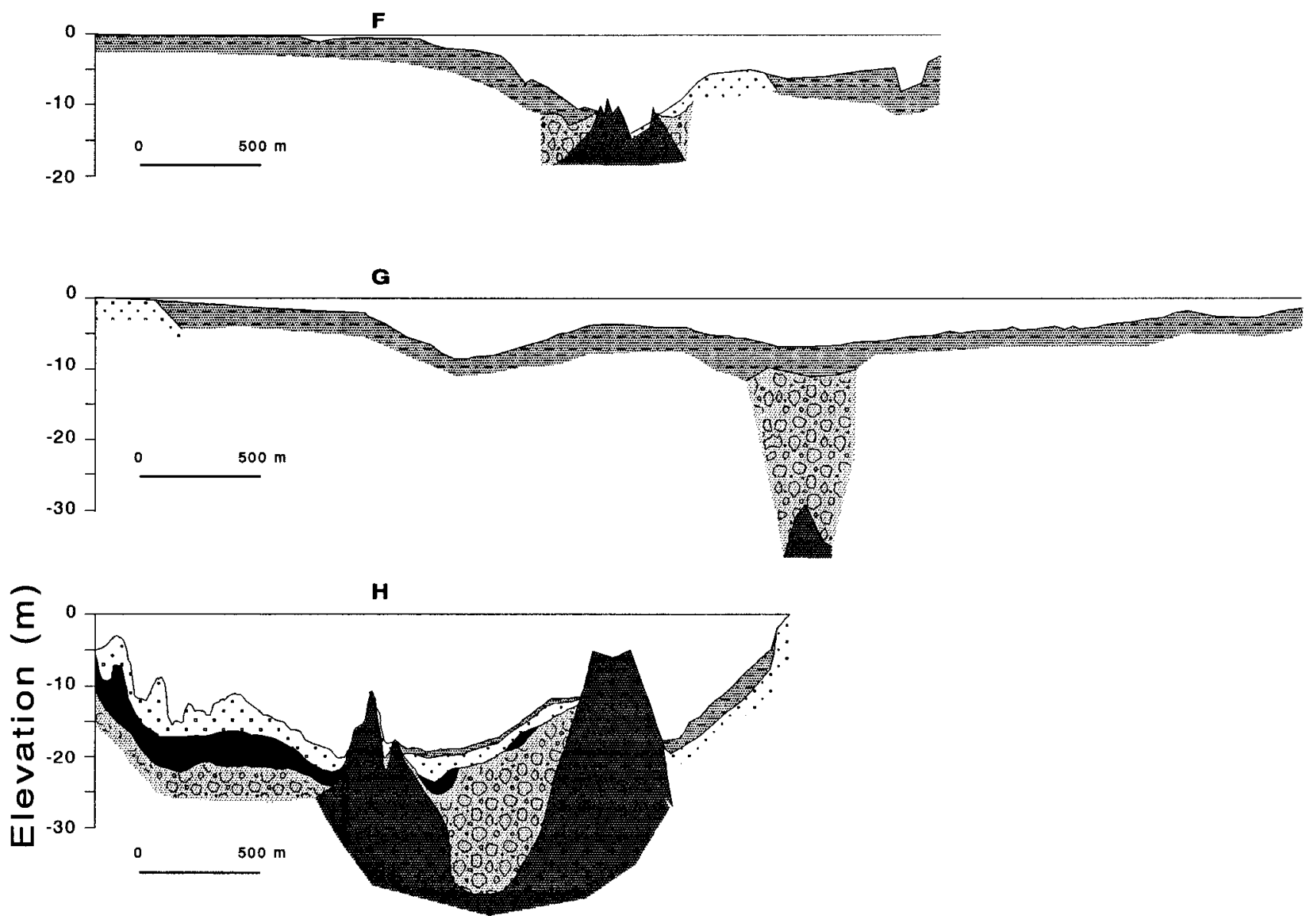

$\mathbf{I}$

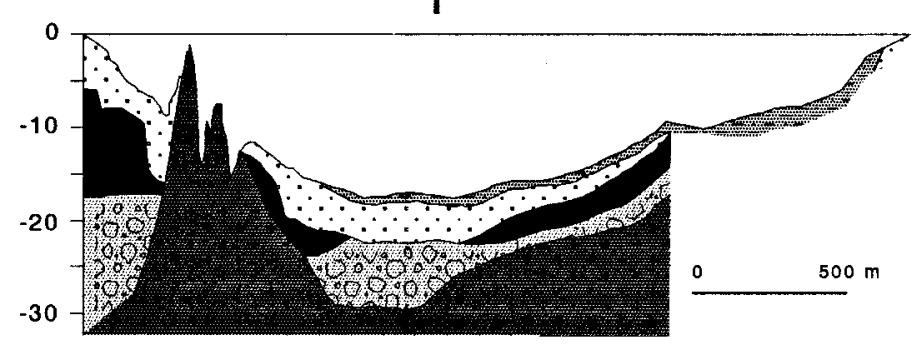

J

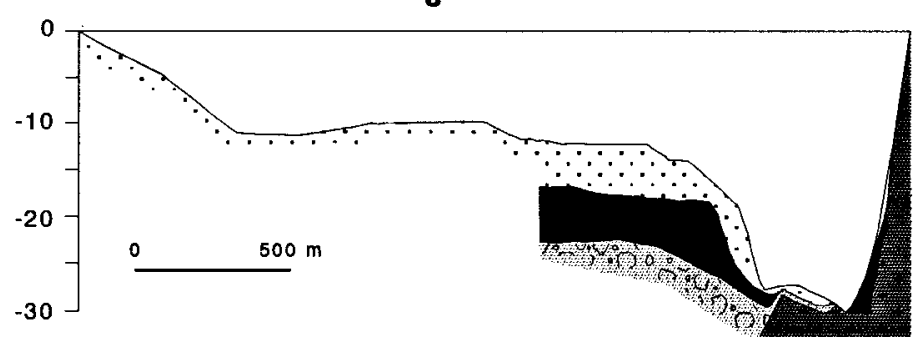

FIG. 12.-Stratigraphic cross sections normal to the estuary axis. See Figure 3 for location of the cross sections.

above and below the sequence boundary. This is observed especially in the upper half of the estuary, where small accommodation space did not allow stratigraphic separation of the lowstand unconformity from subsequent bounding surfaces.

Thick deposits of Facies 2 between cross sections H and J (Figs. 12, 14) were not eroded completely during tidal ravinement because of (1) larger estuarine cross sections and less flow constriction and (2) greater accommodation space, and thicker deposits, in the lower half of the estuary. Although the TTR may be regionally extensive, in the cross sections it is obvious only where the transgressive sand facies and the pre-Holocene fluvial and continental deposits are in direct contact.

Seaward of our study area, transgressive barrier sands may have been 


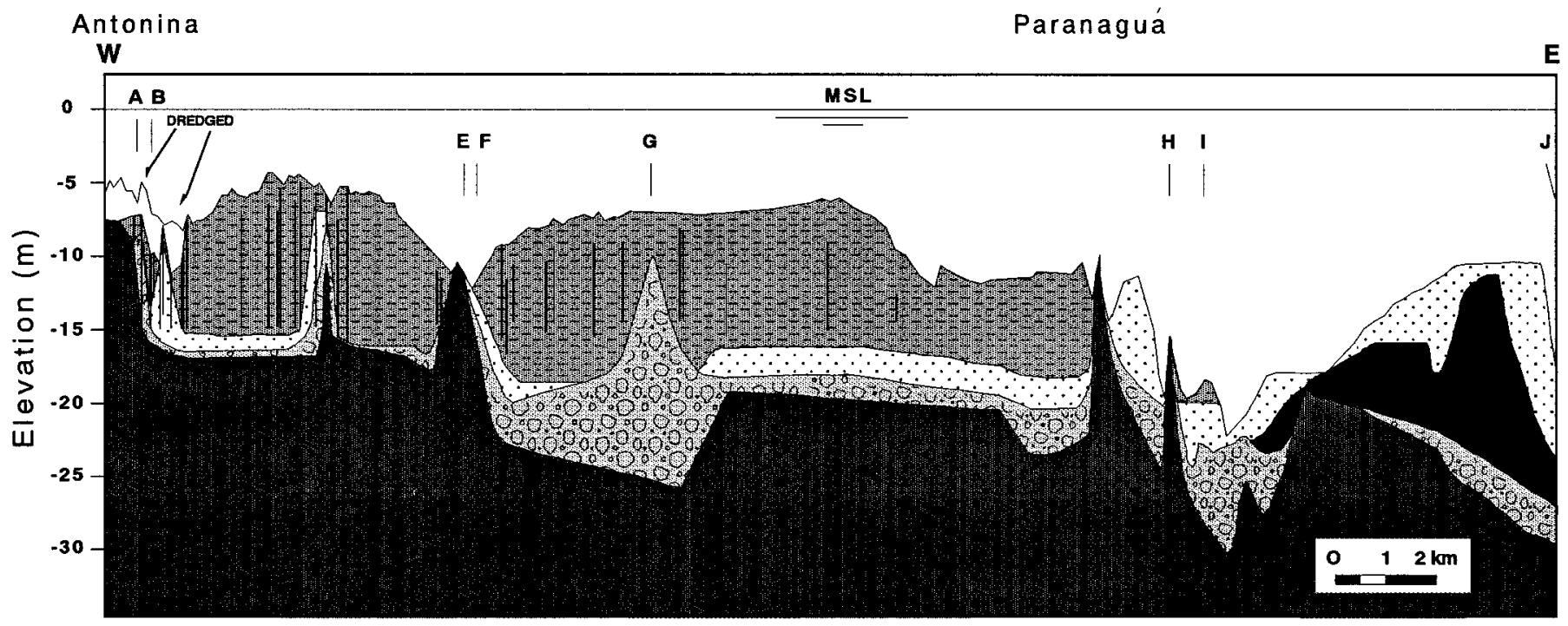

FIG. 13.-Stratigraphic cross section longitudinal to the estuary axis, showing some of the core locations and position of the cross section profiles. The depth of the third and second horizons were mostly determined on the basis of the cores and seismic data, but there are some areas where they are speculative, especially between cross sections $\mathrm{F}$ and $\mathrm{G}$. The transgressive sand facies is proposed to extend beneath the regressive mud west of Paranaguá, at depths not reached by the cores. See also Figure 3 for location of the cross sections.

preserved in the lower part of the Holocene deposits below the WR surrounding and beneath Mel Island (Lessa and Angulo, unpublished work). Mel Island (Fig. 2) is a fragment of a regressive barrier, and coastal progradation in the last 5100 years has caused the outgrowth of the estuary and the possible incorporation of the WR (associated with wave erosion on the transgressing shoreface) within the estuarine confines. These deposits would represent the third component of the TST.

A maximum flooding surface (MFS) separates the TST and the highstand systems tract (HST) (Fig. 14B). However, as observed in Figure 14A, the HST may also overlie the pre-Holocene fluvial and continental deposits, probably separated by a regressive tidal scour surface, i.e., a tidal diastem (TD; see below).

The HST is characterized by the regressive mud facies, which is found within the regressing funnel zone and the regressive (fluvial) sand facies, which is found seaward of the bayline (junction between the estuarine coastal plain and the steeper alluvial plains; Allen and Posamentier 1993). As noted by Allen and Posamentier (1993, 1994), the funnel component of the regressive HST deposits should be similar to the underlying TST tidal deposits.

An active tidal diastem (TD) presently occurs in some locations along the estuary, and can be traced from cross section J (Fig. 14C) to the town of Antonina (cross section A in Figure 11). Unlike the TTR, which was caused by scour concomitant with the deposition of the transgressive sand facies, the TD is due to localized strengthening of ebb-tidal currents. A similar surface is reported for the Qiantangjiang estuary in China (Zhang and Li 1996). By downcutting the channel bed, the TD creates "stratigraphic windows", exposing patches of the transgressive mud facies and the transgressive sand facies, which would normally be buried. The transgressive mud facies crops out just south and west of Cobras Island (Figs. $6,14 \mathrm{C}$ ), whereas strips of the transgressive sand facies are uncovered north of Teixeira's Island (Fig. 6). The observed TD appears to form a sinuous path throughout the estuary, following the ebb-dominated channel(s) (see Oceanography section). Because the zone of strongest currents is spatially dynamic, sediment erosion from tidal scour may have occurred in locations that are not traversed by the present channel. Because of this scour, the regressive mud facies may end up resting on the transgressive mud facies, the transgressive sand facies, the pre-Holocene fluvial and continental deposits, or bedrock, and the TD merges with the TTR.

\section{The Paranaguá Bay Estuary in Perspective}

Investigation of two estuaries morphologically similar to the Paranaguá Bay estuary, namely the James (Nichols et al. 1991) and Gironde (Allen and Posamentier 1993, 1994), allows comparison of stratigraphic successions developed under different Holocene sea-level scenarios (Table 3).

The James is a microtidal barrier estuary located on a transgressing coast (sea level is rising by $1.6 \mathrm{~mm} / \mathrm{y}$ ). It is 2.5 times larger, has a tidal prism three times smaller (smaller tide range), and has comparable rates of freshwater inflow (an indirect measure of potential sediment discharge) in relation to the Paranaguá Bay estuary (Table 3). The James estuary shows the ongoing formation of a TST (Fig. 15). An active TTR is observed in the lower sections of the estuary, where marine sands are deeply incised into the estuary-funnel muds. Also, fluvial sands in the meander zone are being onlapped by the estuary-funnel mud, which is the dominant deposit within the forming succession. Sedimentation rates in the funnel zone are presently outpacing sea-level rise by two orders of magnitude (Nichols et al. 1991), and given the continuation of the process, the estuary might start to develop a HST within a century.

The Gironde is a macrotidal barrier estuary located on a coast where stillstand was reached 4000 years ago. Shoreline recession, however, still takes place because of a negative sediment imbalance on the shoreface. The stratigraphic succession of the Gironde estuary shows an almost complete sequence (Fig. 15). A HST, composed of tidal-estuarine sand and mud (Allen and Posamentier 1994), is presently downlapping onto the TST, whose facies are the prominent sedimentary deposits within the forming sequence (Table 3). Fluvial sand and gravel have not yet prograded over the HST, with coarse sand and gravel deposits being restricted to the rivers landward of the bayline (Allen and Posamentier 1993). In the Paranguá Bay estuary, coarse fluvial sand (see details of the regressive sand facies) has not only overtaken the bayline but also appears to be actively migrating into the thalweg of the estuary funnel zone (Fig. 15). This discrepancy can be ascribed to the discharge of high-energy rivers directly into the meandering zone of Paranaguá Bay estuary. While river gradient for the Gironde 
A

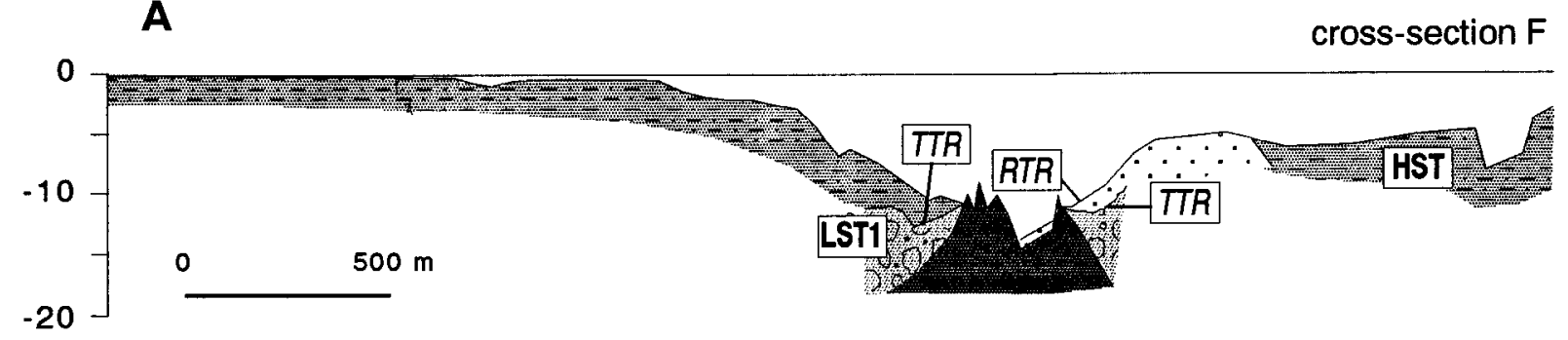

B
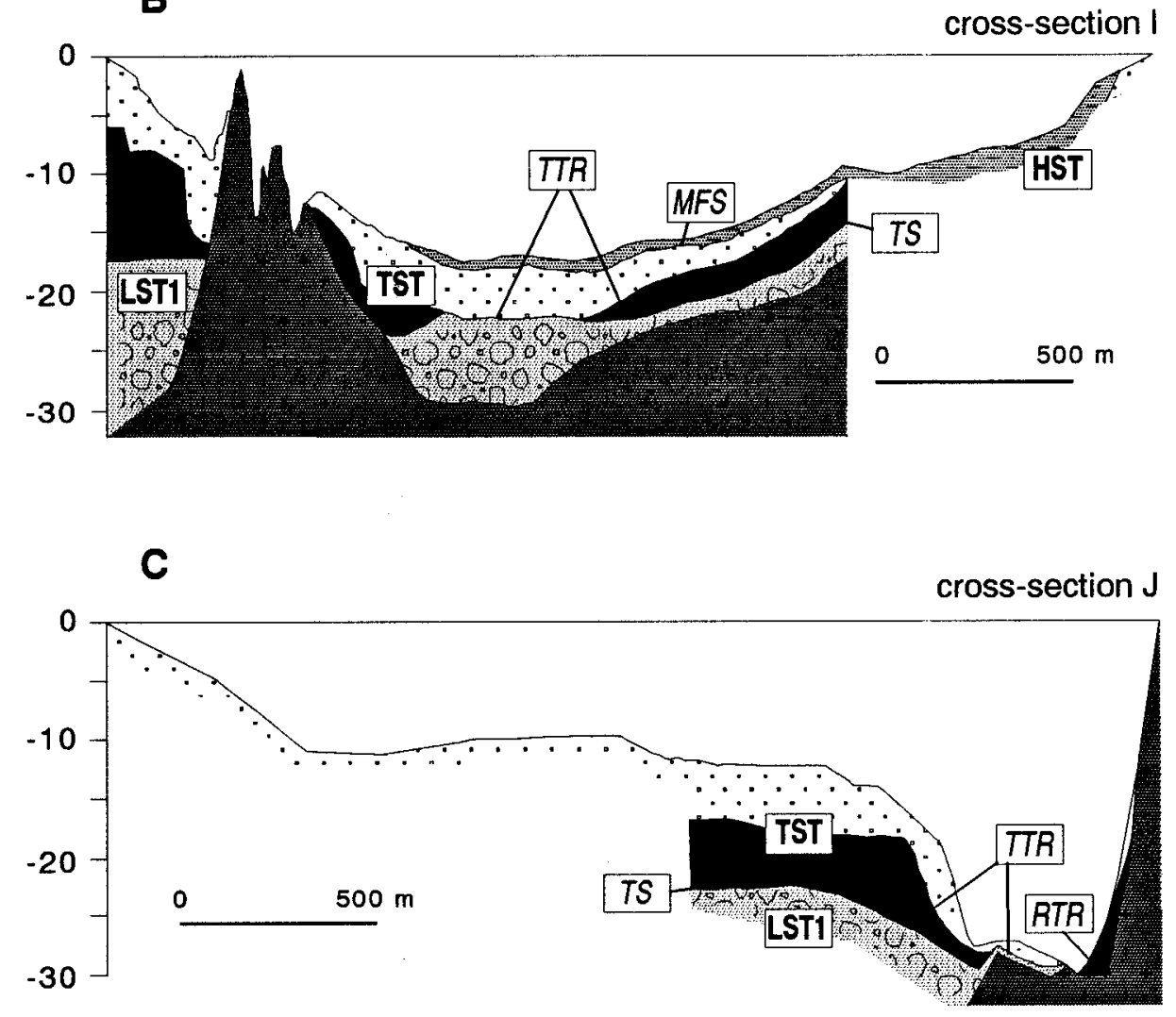

FIG. 14.-Sequence stratigraphic interpretation of three cross sections of the Paranaguá Bay estuary. See Figure 3 for location of the cross sections.

estuary is around 1:1000, the steepness of the catchment area just upstream of the meandering zone in Paranaguá Bay estuary can be as high as 1:15 (see Hydrography section).

The HST in the Gironde estuary is areally extensive, given the stillstand condition. About $80 \%$ of the estuary is covered by the deposits of the HST, in comparison to approximately $67 \%$ of the Paranaguá Bay estuary. Such broad distribution can be ascribed to the smaller volume of the Gironde estuary in relation to the fresh-water input when compared to the Paranaguá Bay estuary (larger flushing time; Table 3). Although there are no estimates of sediment discharge for the Paranaguá Bay estuary, larger (absolutely and relatively) fresh-water discharges in the Gironde estuary may imply a greater discharge of solids and, consequently, higher infilling rates. This can also be inferred by comparing the thickness of the Holocene sediment fill in both estuaries, which attained a maximum of more than $30 \mathrm{~m}$ in the Gironde estuary and about $10 \mathrm{~m}$ in the Paranaguá Bay estuary (Fig. 13).

Differences in the relative extent of the transgressive sand facies is also indicated in Figure 15. Most of the TST in the Gironde estuary is composed of tidal-estuarine sand and mud comprising three major sedimentary facies: sand/mud laminae, flasers, and drapes; estuarine mud; and carbonaceous clay (Allen and Posamentier 1993). The marine sands in the Gironde occupy only $20 \mathrm{~km}(\approx 16 \%)$ of the estuary length. Within the TST of the Paranaguá Bay estuary, the transgressive marine sand facies is the most extensive, and appears to be present at least within the initial $25 \mathrm{~km}$ of the estuary (or $50 \%$ of the estuary length). The difference in the extent of intrusion of marine sand in these two estuaries may be partially due to coastal progradation $(\approx 10 \mathrm{~km})$ in the Paranaguá Bay estuary since the highstand. However, flood-tidal transport also appears to have been more efficient in the Paranaguá Bay estuary, resulting in farther intrusion of the marine sands.

The presence of marine sands, as well as the TTR, apparently as far as cross section F (Fig. 14) in the Paranaguá Bay estuary, is a small variation from the stratigraphic model of Zaitlin et al. (1994). In this model, the incised-valley system is divided into three segments: (1) a landward segment, which never experiences marine influence and remains fluvial 
TABLE 3.-Comparison of the Paranaguá Bay estuary, Gironde estuary and James estuary. Information on the Gironde estuary was compiled from Allen et al. (1980) and Allen and Posamentier (1993, 1994), and information on the James estuary was gathered from Nichols et al. (1991).

\begin{tabular}{|c|c|c|c|c|c|c|}
\hline Estuary & $\begin{array}{l}\text { Estuary } \\
\text { Classification }^{1} \\
\text { and Coastline } \\
\text { trend }\end{array}$ & $\begin{array}{l}\text { Holocene Sea } \\
\text { Level Trend } \\
\text { and Present } \\
\text { Estuary Status }\end{array}$ & $\begin{array}{l}\text { Status of } \\
\text { LST, TST } \\
\text { and HST }\end{array}$ & $\begin{array}{l}\text { Dominant } \\
\text { Deposit } \\
\text { within the } \\
\text { Sequence }\end{array}$ & $\begin{array}{l}\text { Fresh } \\
\text { Water } \\
\text { Inflow } \\
\left(\mathrm{m}^{3} / \mathrm{s}\right)^{3}\end{array}$ & $\begin{array}{l}\text { Flushing } \\
\text { Time } \\
\text { (days) }^{4}\end{array}$ \\
\hline $\begin{array}{l}\text { Paranaguá } \\
\text { Bay, Bra- } \\
\text { zil }\end{array}$ & $\begin{array}{l}\text { microtidal, wave- } \\
\text { dominated pro- } \\
\text { grading }\end{array}$ & falling, regressive & $\begin{array}{l}\text { developed } \\
\text { developed } \\
\text { developed }\end{array}$ & $\begin{array}{l}\text { Regressive Mud } \\
\text { Facies of HST }\end{array}$ & 200 & 81 \\
\hline $\begin{array}{l}\text { Gironde, } \\
\text { France }\end{array}$ & $\begin{array}{l}\text { macrotidal, mixed } \\
\text { tide- and wave- } \\
\text { dominated retro- } \\
\text { grading }\end{array}$ & $\begin{array}{l}\text { stillstand, regres- } \\
\text { sive }\end{array}$ & $\begin{array}{l}\text { developed } \\
\text { developed } \\
\text { developed }\end{array}$ & $\begin{array}{l}\text { Transgressive Es- } \\
\text { tuarine Sand- } \\
\text { Mud Facies of } \\
\text { TST }\end{array}$ & 760 & 32 \\
\hline $\begin{array}{l}\text { James River, } \\
\text { Virginia }\end{array}$ & $\begin{array}{l}\text { microtidal, wave- } \\
\text { dominated retro- } \\
\text { grading }\end{array}$ & $\begin{array}{l}\text { rising, transgres- } \\
\text { sive }\end{array}$ & $\begin{array}{l}\text { developed } \\
\text { initiated } \\
\text { not pres- } \\
\text { ent }\end{array}$ & $\begin{array}{l}\text { Transgressive } \\
\text { Mud or Shale } \\
\text { Facies of TST }\end{array}$ & 132 & 138 \\
\hline
\end{tabular}

${ }^{1}$ Classification for Gironde and James River presented in the referred papers.

${ }^{2}$ This is a preliminary finding. Since deposits seaward of Cobras Island were outside of our data set, we were unable to evaluate the thicknesses of the sediments deposited there.

${ }^{3}$ High inflow.
${ }^{4}$ Volumetric subtidal estuary capacity divided by average river inflow. throughout infilling; (2) a middle segment, which corresponds to the incised valley at the time of maximum transgression, and (3) an outer segment, which is transgressed by the shoreline and contains a transgressive succession of fluvial and marine facies. Marine sands are confined to the outer segment and the initial extent of the middle segment (marine sands are absent in the middle part of the middle segment). The departure of the Paranguá Bay estuary from this model (cross section $\mathrm{F}$ is in the upper half of the estuary associated with the maximum transgression) is possibly related to its hypersynchronous tidal characteristics, which enables the maintenance of the tidal current energy (and sediment transport capacity) after the flow passes the inlet.

It is worth noting, however, that the Paranguá Bay estuary has an ebbdominated tidal current regime, which is detrimental to intrusion of marine sands so far into the estuary (much farther upstream than the shoreline at the transgression maximum). It appears that some kind of morphodynamic change, causing ebb-dominant tidal conditions, may have occurred with the partial infilling of the Paranaguá Bay estuary (see also Boon and Byrne 1981; Lessa 1994; van Dongeren and de Vriend 1994; Lessa and Masselink 1995; van der Spek 1997) (this hypothesis is presently under investigation). Other supporting evidence for this conjecture are the extensive flood-tidal delta deposits that form most of Guraraguaçu Island (Fig. 2) (Lessa and Angulo unpublished work), and the existence of open-marine bivalve and gastropod species within tidal deposits (vibracore \#1), implying that net-flood sediment transport in the estuary occurred in the past. Restrictions to marine sediment intake means that further infilling of the estuary relies on fluvial sediment sources.

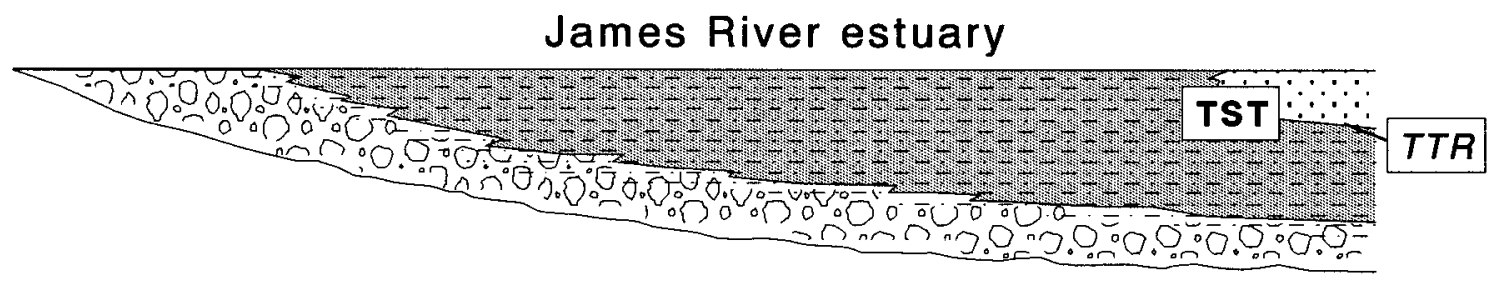

Gironde estuary
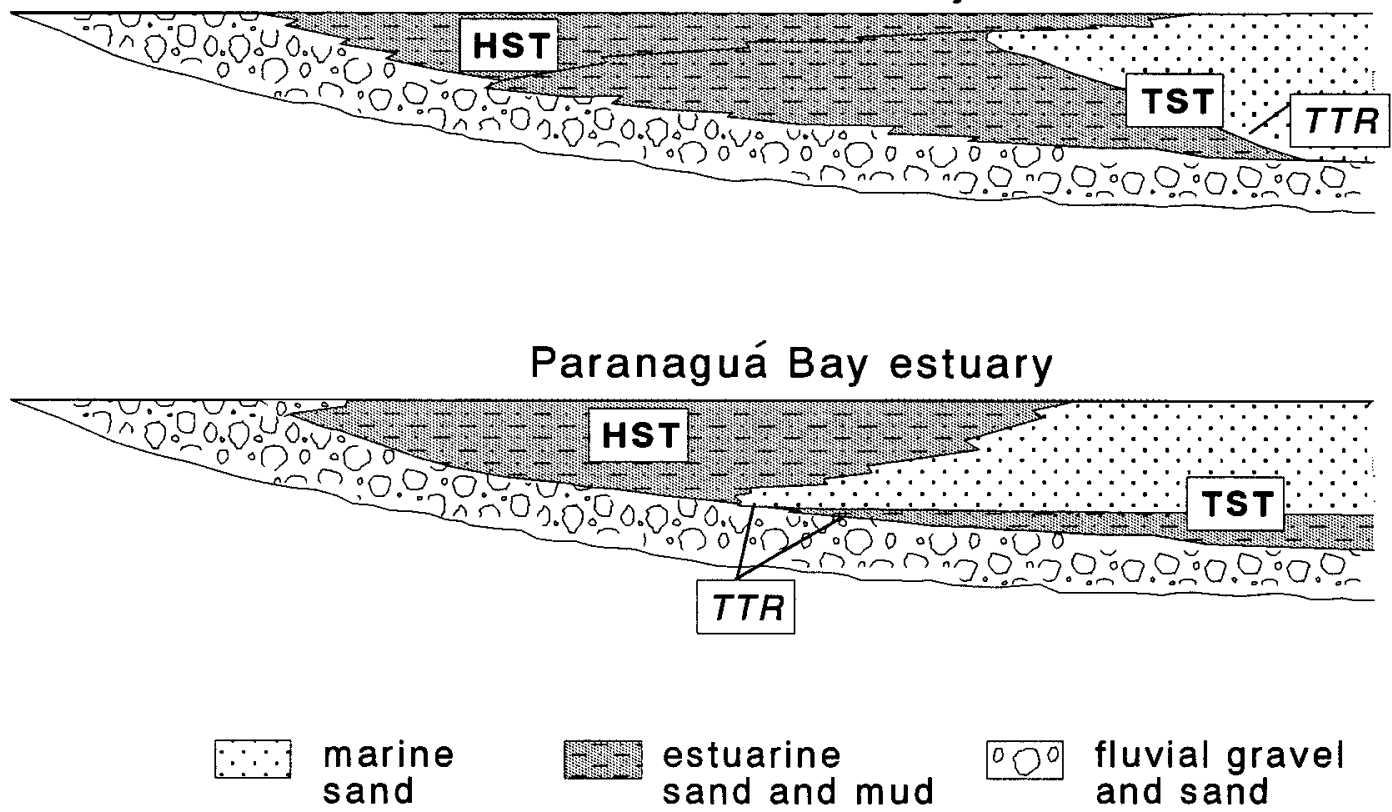

FIG. 15.-Schematic lithologic sections along the longitudinal estuary axes of the James, Gironde, and Paranaguá Bay estuaries. The mud deposits in the Gironde estuary are part of the transgressive and highstand system tracts. 


\section{CONCLUSIONS}

A compilation of data sets concerning surface and subsurface sediments of the Paranaguá Bay estuary allowed for an initial description and evaluation of the Quaternary stratigraphy along the main axis of the estuary. An almost complete stratigraphic sequence was identified, composed of three regressive and two transgressive sedimentary facies, separated by important bounding surfaces. A sequence boundary (SB) must lie within the pre-Holocene fluvial and continental deposits, where erosion appears to have removed most or all of the incised-valley sequences associated with former transgressions. The transgressive system tract is composed of the transgressive mud facies and the transgressive sand facies. The transgressive mud facies seems to be the oldest Holocene sedimentary deposit of the incised valley fill, because fluvial sand above the flooding surface (FS) has not been identified. The transgressive mud facies is not observed in the upper half of the estuary, where smaller accommodation space existed and more intense tidal scouring, due to flow constriction, may have taken place. The transgressive sand facies seems to have migrated into the upper half of the estuary, which is at odds with the current hydrodynamic regime, which favors ebb-directed net sediment transport.

The transgressive surface (TS) seems to coincide with this estuarine/ fluvial contact, which appears to be the case in scenarios where little fluvial sediment is being deposited at the head of the estuary during transgression. Ravinement surfaces are associated with the increasing tidal-current action during transgression (transgressive tidal ravinement; TTR), with enhanced tidal flow along ebb-dominated parts of the channel axis (tidal diastem; $\mathrm{TD}$ ), and with wave erosion on the shoreface during transgression (wave ravinement; WR). A maximum flooding surface (MFS), at the boundary between the transgressive and the highstand system tracts, lies within the central basin facies. Because of strong tidal-current activity and small accommodation space in parts of the estuary, the TTR and the TD appear to merge locally. The ongoing channel erosion caused by the TD locally creates "stratigraphic windows", exposing patches of the transgressive mud facies and the transgressive sand facies on the estuary floor.

A regressive mud facies is found within the regressing funnel zone, which includes the prograding bay-head delta, and is at present the most extensive sedimentary deposit within the estuary. Along with the regressive sand facies, restricted to the head of the estuary, they form the highstand system tract.

\section{ACKNOWLEDGMENTS}

We would like to thank the Antonina Harbor Authority for making available the sediment samples derived from the jet-probe cores, and the Paranaguá Harbor Authority (especially Mrs. Maria Manoela Oliveira) for providing access to their map library and making several copies of bathymetric and seismic charts from the lower half of the estuary. Cia. Docas do Rio de Janeiro provided a copy of the seismic charts that covered the area between Paranaguá and Antonina and the Directory of Hydrography and Navigation (DHN-Rio de Janeiro) supplied several copies of the onboard bathymetric charts. R.W. Dalrymple and M.R. Gibling are acknowledged for many helpful comments, which greatly improved the quality of the manuscript. Thanks also go to Marcia Bernini and Ghisi de Oliveira for their help with the sediment analysis.

\section{REFERENCES}

Allen, G.P., and Posamentier, H.W., 1993, Sequence stratigraphy and facies model of an incised valley fill: the Gironde estuary, France: Journal of Sedimentary Petrology, v. 63, p. 378-392.

Allen, G.P., and Posamentier, H.W., 1994, Transgressive facies and sequence architecture in mixed tide-and wave-dominated incised valleys: example from the Gironde estuary, France, in Dalrymple, R., and Boyd, R., eds., Incised-Valley Systems: Origin and Sedimentary Sequences: SEPM, Special Publication 51, p. 225-239.

Allen, G.P., Salomon, J.C., Dupenhoat, C., and De Grandpre, C., 1980. Effects of tides on mixing and suspended sediment transport in macrotidal estuaries: Sedimentary Geology, v. 26, p. $62-80$.

Angulo, R.J., 1992, Geologia da Planície Costeira do Estado do Paraná [unplublished Ph.D. thesis]: Universidade de São Paulo, Instituto de Geociências, 332 p.

Angulo, R.J., 1995, Caracterização e reavalização da Formação Alexandra (Terciário) e dos sedimentos continentais associados a vertentes, no litoral do Estado do Paraná, Brasil [Characterization and reevaluation of the Alexandra Formation (Tertiary) and continental sediments associated with hillsides, on the coast of the state of Paraná, Brazil]: Academia Brasileira de Ciências, Anais, v. 67, p. 443-463.

Angulo, R.J., AND LeSSA, G.C., 1997, The Brazilian sea level curves: a critical review with emphasis on the curves from Paranaguá and Cananéia regions: Marine Geology, v. 140, p. 141-166.

Angulo, R.J., And Suguio, K., 1995, Re-evaluation of the Holocene sea-level maxima for the State of Paraná, Brazil: Palaeogeography, Palaeoclimatology, Palaeoecology, v. 113, p. 385393.

Bigarella, J.J., 1946, Contribuição ao estudo da planície litorânea do Estado do Paraná: Arquivos Biologia Tecnologia, v. 1, p. 75-11.

Bigarella, J.J., 1971, Variações climáticas no Quaternário Superior do Brasil e sua datação radiométrica pelo método do Carbono 14: Paleoclimas, v. 1, p. 1-22.

Bigarella, J.J., Becker, R.D., Mattos, D.J., and Werner, A., 1978, A Serra do Mar e a Porção Oriental do Estado do Paraná: Curitiba, Brazil, SEPL/ADEA, 249 p.

Boon, J.D., AND ByrNe, R.J., 1981, On basin hypsometry and the morphodynamic response of coastal inlets: Marine Geology, v. 40, p. 27-48.

Boyd, R., AND HonIG, C., 1992, Estuarine sedimentation on the eastern shore of Nova Scotia: Journal of Sedimentary Petrology, v. 62, p. 569-583.

Boyd, R., Dalrymple, R., and Zaituin, B.A., 1992, Classification of coastal depositional environments: Sedimentary Geology, v. 80, p. 139-150.

Chappell, J., 1993, Contrasting Holocene sedimentary geologies of lower Daly River, northern Australia, and lower Sepik-Ramu, Papua New Guinea: Sedimentary Geology, v. 83, p. 339358.

Companhia Brasileira de Dragagem, 1980, Relatório Final dos Levantamentos Geofísico e Batimétrico Realizados na Região da Baía de Paranaguá, no Estado do Paraná. Rio de Janeiro, 11 p. (unpublished charts and report).

Dalrymple, R.W., Zaitlin, B.A., AND Boyd, R., 1992, Estuarine facies models: conceptual basis and stratigraphic implications: Journal Sedimentary Petrology, v. 62, p. 1130-1146.

Davis, R.A., JR., AND HEALY, T.R., 1993, Holocene coastal depositional sequences on a tectonic active setting: southeastern Tauranga Harbor, New Zealand: Sedimentary Geology, v. 84, p. $57-69$.

ENCAL, 1972, Paranaguá Geophysical Survey Technical Report, 135 p. (unpublished charts and report).

FREY, R.W., AND Howard, J.D., 1986, Mesotidal estuarine sequences: a perspective from the Georgia Bight: Journal of Sedimentary Petrology, v. 56, p. 911-924.

Friedrichs, C.T., AND Aubrey, D.G., 1988, Non-linear tidal distortions in shallow well-mixed estuaries: a synthesis: Estuarine, Coastal and Shelf Science, v. 27, p. 521-545.

FrY, V.A., AND AubreY, D.G., 1990, Tidal velocity asymmetries and bedload transport in shallow embayments: Estuarine, Coastal and Shelf Science, v. 30, p. 453-473.

ipardeS (Instituto Paranaense de Desenvolviemnto Econômico e Social), 1990, Macrozoneamento da APA de Guaraqueçaba: Curitiba, Brazil, IPARDES, 257 p.

IPARDES (Instituto Paranaense de Desenvolvimento Econômico e Social), 1991, Diagnóstico físico-ambiental da Serra do Mar área sul: Curitiba, Brazil, IPARDES, 107 p.

IPQM, 1969, Estudo das correntes na Baía de Paranaguá. Paranaguá Harbor's Archives (unpublished).

Knoppers, B.A., Brandini, F.P., and Thamm, C.A., 1987, Ecological studies in the Bay of Paranaguá. II. Some physical and chemical characteristics: Nerítica, v. 2, no. 1, p. 1-36.

LESSA, G.C., 1994, Morphodynamics and evolution of two small macrotidal Estuaries-Central Queensland, Australia [unpublished Ph.D. thesis]: University of Sydney, Sydney, Australia, $246 \mathrm{p}$.

Lessa, G.C., AND ANgulo, R.J., 1995, A framework for the stratigraphy and evolution of the Paranaguá coastal plain-Paraná, Brazil: II Congresso da Associção Brasileira para Estudos do Quaternário (ABEQUA), Niterói, Brazil, Anais, p. 92-98.

Lessa, G.C., ANd Masselink, G., 1995. Sedimentation and hydrodynamic changes in a backbarrier macrotidal estuary: a morphodynamic approach: Marine Geology, v. 129, p. 25-46 MAACK, R., 1968, Geografia Física do Estado do Paraná: Curitiba, Brazil, M. Roesner, 350 p. Marone, E., And de Camargo, R., 1994, Marés meteorológicas no litoral do Estado do Paraná: o evento de 18 de agosto de 1993: Nerítica, v. 8, no. 1-2, p. 73-85.

Marone, E., and JamiYanaA, D., 1998, Tides and tidal modelling in the Paranaguá Bay, PR: Nerítica, in press.

Martin, L., Suguio, K., Flexor, J.M., and Azevedo, A.E.G., 1988, Mapa geológico do Quaternário costeiro dos Estados do Paraná e Santa Catarina: Série Geol. DNPM, 28, 40 p.

Nichol, S.L., 1991, Sedimentology of two wave dominated, incised valley estuaries: New South Wales South Coast [unpublished Ph.D. thesis]: University of Sydney, Sydney, Australia, $501 \mathrm{p}$.

Nichol, S.L., Boyd, R., and Penland, S., 1994, Stratigraphic response of wave dominated estuaries to different relative sea-level and sediment supply histories: Quaternary case studies from Nova Scotia, Louisiana and eastern Australia, in Dalrymple, R., and Boyd, R., eds., Incised-Valley Systems: Origin and Sedimentary Sequences: SEPM, Special Publication 51, p. 265-283.

Nichols, M.M., Johnson, G.H., And Peebles, P.-C., 1991, Modern sediments and facies model for a microtidal coastal plain estuary, the James River Estuary, Virginia: Journal of Sedimentary Petrology, v. 61, p. 883-899.

PORTOBRÁS, 1988, Levantamento Sísmico nas Proximidades do TECON, Porto de Paranaguá (unpublished charts).

PROGEO, 1993, Relatório de Sondagens Geológicas do Canal de Acesso e Bacia de Evolução do Porto de Antonina-PR: Belo Horizonte, 130 p. (unpublished)

Roy, P.S., 1984, New South Wales estuaries: their origin and evolution, in Thom, B.G., ed., Coastal Geomorphology in Australia: Sydney, Australia, Academic Press, p. 99-121.

RoY, P.S., 1994, Holocene estuary evolution—stratigraphic studies from southeastern Australia, 
in Dalrymple, R., and Boyd, R., eds., Incised-Valley Systems: Origin and Sedimentary Sequences: SEPM, Special Publication 51, p. 241-263.

SHI, Z., AND Lamb, H.F., 1991, Post-glacial sedimentary evolution of a microtidal estuary, Dyfi Estuary, west Wales, U.K: Sedimentary Geology, v. 73, p. 227-246.

Soares, C.R., And Lana, P.C., 1994, Baía de Paranaguá: Mapas e Histórias: Curitiba, Brazil, Editora da UFPR, 98 p.

Soares, C.R, Lessa, G.C., Neto, A.G., Riesemberg, C.E., and Silva, C.B., 1996, Caracterização da distribuição dos sedimentos de fundo das baías de Paranaguá e Antonina, Estado do Paraná: Anais, XXXIX Congresso Brasileiro de Geologia, Salvador, 1-6 de setembro de 1996, Anais, vol. 3, p. 390-393.

Suguio, K., Martin, L., Bittencourt, A.C.S.P., Dominguez, J.M.L., Flexor, J.M., And Azevedo, A.E.G., 1985, Flutuações do nível relativo do mar durante o Quaternário Superior ao longo do litoral brasileiro e suas implicações na sedimentação costeira: Revista Brasileira de Geociências, v. 15 , p. $273-286$.

VAN DER SPEK, A.J.F., 1997, Tidal asymmetry and long-term evolution of Holocene tidal basins in the Netherlands: simulation of palaeo-tides in the Schelde estuary: Marine Geology, v. 141, p. 71-90.

van Dongeren, A.R., And de VRIend, H.J., 1994, A model of morphological behaviour of tidal basins: Coastal Engineering, v. 22, p. 287-310.
Van Wagoner, J.C., Posamentier, H.W., Mitchum, R.M., Vail, P.R., SARG, J.F., Loutit, T.S., AND Hardenbol, J., 1988, An overview of the fundamentals of sequence stratigraphy and key definitions, in Wilgus, C.K., Hastings, B.S., Kendall, C.G.St.C., Posamentier, H.W., Ross, C.A., and Van Wagoner, J.C., Sea-Level Changes: An Integrated Approach: SEPM, Special Publication 42, p. 39-45.

Woodroffe, C.D., Chappell, J., Thom, B.G., and Wallensky, E., 1989, Depositional model of a macrotidal estuary and floodplain, South Alligator River, northern Australia: Sedimentology, v. 36, p. 737-756.

Woodroffe, C.D., Mulrennan, M.E., and Chappell, J., 1993, Estuarine infill and coastal progradation, southern van Damien Gulf, northern Australia: Sedimentary Geology, v. 83, p. $257-275$.

Zaitlin, B.A., Dalrymple, R.W., and Boyd, R., 1994, The stratigraphic organization of incised valley systems associated with relative sea-level change, in Dalrymple, R., and Boyd, R., eds., Incised-Valley Systems: Origin and Sedimentary Sequences: SEPM, Special Publication 51 , p. 265-283

Zhang, G., AND Li, C., 1996, The fills and stratigraphic sequences in the Qiantangiiang incised paleovalley, China: Journal of Sedimentary Research, v. 66, , p. 406-414.

Received 17 January 1997; accepted 19 April 1998. 